\title{
The concept of Account- Lists in Ancient Egypt
}

\author{
Nesma I. Mohamed \\ Faculty of Arts, Egyptology Department \\ New Valley University, Egypt \\ N.Ibrahim@artnv.au.edu.eg
}

\begin{abstract}
This paper presents a detailed explanation is included the concept of Account- Lists appeared in ancient Egypt, and this is evidenced by the huge number of these documents written in hieratic and then demotic; The texts of this quality included (tax records, agendas, grain distribution tables, accounting tables, distribution records of wages and receivables, food orders, materials Lists of various items and materials, lists of the contents of the temples, documents for the transfer and delivery of materials and yields).Then presented the terms related to the mathematical text and similarly wages and taxes. The study concluded with the presentation of the written form of the texts Full detailed explanation followed by the conclusion.
\end{abstract}

Key Words: Account, List, Arithmetic, Mathematical, Wage, Daybooks, Tax.

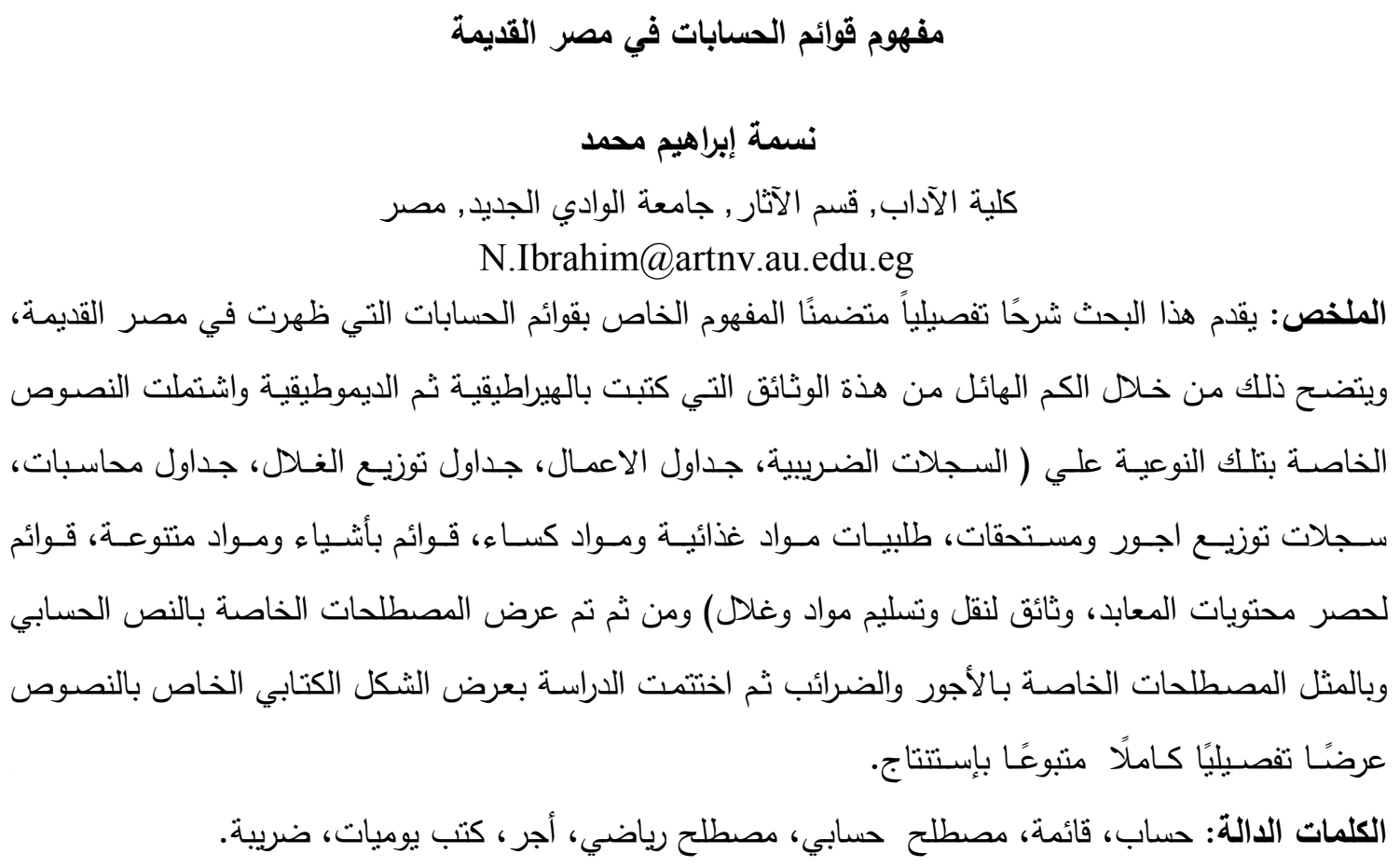


Will discuss the issue through several points:

- Terminology.

- Computational reporting.

- Daybooks.

- Wages records \& income of individuals.

- Tax reports.

- Categories.

- General Form.

\section{Terminology:}

Although there is no term describing or refer to the Arithmetic or Statistical form in some papyri, there are expressions that refer to the different mathematical and statistical forms as titles ${ }^{1}$ :

\begin{tabular}{|c|c|c|c|c|}
\hline Term & Texts & Source & Transcript & Remarks \\
\hline \multirow[t]{6}{*}{$h s b$} & A- Abu- sir & \multirow{6}{*}{$\begin{array}{l}\text { Wb, III, } 166 \\
\text { Faulkner, CD, } \\
178 \\
\text { LD, } 140 . \\
\text { Ranier Hannig, } \\
\text { Handworterbuch, } \\
\text { KAW, Band } 64, \\
\text { (Berlin: Philipp } \\
\text { von zebern } \\
\text { 1995), } 1554 \\
\text { DELC, } 313\end{array}$} & $\bigcap_{x}$ & \multirow{6}{*}{$\begin{array}{l}\text { Calculates \& } \\
\text { Calculates or } \\
\text { budget } \\
\text { Continued } \\
\text { writing during } \\
\text { Coptic language } \\
\text { in these biblical } \\
\text { forms } \\
\text { 2осв€, 2ОСв } \\
\text { 2дСв€ }\end{array}$} \\
\hline & $\begin{array}{l}\text { B- Boulaq } \\
\text { Papyrus } 18\end{array}$ & & 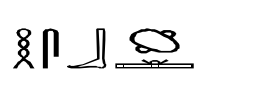 & \\
\hline & $\begin{array}{l}\text { C- Louvre } \\
\text { Panvrus F } 3226\end{array}$ & & @ & \\
\hline & D- Raisner & & 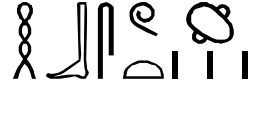 & \\
\hline & $\begin{array}{l}\text { Papyrus } 1 \\
\text { E- Kahun }\end{array}$ & & $\int e \sum_{\infty}=$ & \\
\hline & Papyrus & & $81] \Rightarrow 0$ & \\
\hline \multirow[t]{3}{*}{${ }^{c} h^{\top} t$} & $\begin{array}{l}\text { A- Rhind Papyrus } \\
\text { Mathematical }\end{array}$ & & 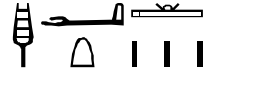 & \multirow{3}{*}{$\begin{array}{l}\text { Total } \\
\text { Quantity } \\
\text { amount } \\
\text { List }\end{array}$} \\
\hline & B- Mosco & rauikner, CD & 貝 $=0$ & \\
\hline & $\begin{array}{l}\text { Mathematical } \\
\text { C- Kahun }\end{array}$ & & I l & \\
\hline
\end{tabular}

\footnotetext{
${ }^{1}$ Mohamed Sherif, "A collection of administrative hierarchies in the Egyptian Museum comparative linguistic study" (unpublished MA thesis, Cairo University, Faculty of Archeology, 1989) 8 .
} 
The concept of Account-Lists in Ancient Egypt

\begin{tabular}{|c|c|c|c|c|}
\hline & $\begin{array}{l}\text { Papyrus } \\
\text { D- Hieratic } \\
\text { Ostraka }\end{array}$ & & & \\
\hline \multirow[t]{8}{*}{$R h t$} & $\begin{array}{l}\text { A-Thothmosis III } \\
\text { Annuals in } \\
\text { Karnak }\end{array}$ & $\begin{array}{l}\text { Wb, II, } 448 \\
\text { CD, } 152 . \\
\text { LD, I, } 68 .\end{array}$ & $\hat{\theta}_{\theta_{0}}$ & \multirow{8}{*}{$\begin{array}{l}\text { List quantities or } \\
\text { List the amount } \\
\text { or } \\
\text { A known } \\
\text { account }\end{array}$} \\
\hline & \multirow{4}{*}{$\begin{array}{l}\text { B- Raizner } \\
\text { Papyrus II } \\
\text { C- Boulaq } \\
\text { Papyrus II } \\
\text { D- Egyptian } \\
\text { Museum Papyrus }\end{array}$} & & $\hat{\theta \infty}_{\theta \infty}$ & \\
\hline & & & $\widehat{\theta}_{\theta 111}$ & \\
\hline & & & 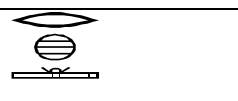 & \\
\hline & & & $\mathrm{O}^{\theta}$ & \\
\hline & No 58072 & & $\bar{\theta}$ & \\
\hline & E- New kingdom & & $\begin{array}{l}0 \\
\theta \\
\theta\end{array}$ & \\
\hline & $\begin{array}{l}\text { F- Kahun } \\
\text { Papyrus }\end{array}$ & & 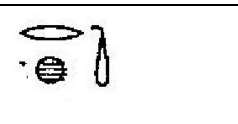 & \\
\hline \multirow[t]{2}{*}{ Imy-rn.f } & $\begin{array}{l}\text { A- Kahun } \\
\text { Papyrus }\end{array}$ & $\mathrm{Wb}, \mathrm{I}, 74,15$ & 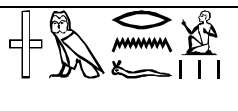 & \multirow{2}{*}{$\begin{array}{l}\text { Names list } \\
\text { Sometimes } r n \\
\text { is written only in } \\
\text { the demotic } \\
\text { accounts by } \\
\text { these two forms } \\
\text { I/ }\end{array}$} \\
\hline & $\begin{array}{l}\text { B- Raisner } \\
\text { Papyrus } 1 \\
\text { C- Raisner } \\
\text { Papyrus II } \\
\text { D- Anstasi } \\
\text { Papyrus IV }\end{array}$ & $\begin{array}{l}\text { LD, III, BL, } \\
\text { 12,c } \\
\text { Haning,Wb } \\
1434 \\
\text { CDD, } 47 \\
\text { Er. Glossar. } 249 .\end{array}$ & & \\
\hline$\check{s} s$ & $\begin{array}{l}\text { A- Louvre } \\
\text { Papyrus E } 3226\end{array}$ & & سـ & $\begin{array}{l}\text { an document and } \\
\text { translated when } \\
\text { it appears in a }\end{array}$ \\
\hline
\end{tabular}


The concept of Account-Lists in Ancient Egypt

\begin{tabular}{|c|c|c|c|c|}
\hline & $\begin{array}{l}\text { B-Heka Nkht } \\
\text { Papers }\end{array}$ & $\begin{array}{l}\text { Wb, III, 476,14 } \\
\text { Faulkner, CD, } \\
246 .\end{array}$ & & $\begin{array}{l}\text { statistical } \\
\text { document with } \\
\text { an accounting } \\
\text { document or a } \\
\text { list }{ }^{1} \text { As in the list } \\
\text { of Heka Nacht }^{2}\end{array}$ \\
\hline \multirow[t]{4}{*}{$R d y t$} & \multirow{3}{*}{$\begin{array}{l}\text { A- Boulaq } \\
\text { Papyrus II }\end{array}$} & \multirow{4}{*}{$\begin{array}{l}\text { Wb, V, } 419 \\
\text { Faulkner, CD, } \\
154 .\end{array}$} & $\frac{\partial}{0}$ & \multirow{4}{*}{$\begin{array}{l}\text { Statistical } \\
\text { registration \& } \\
\text { The material is } \\
\text { statistically } \\
\text { recorded }\end{array}$} \\
\hline & & & ו ו ו & \\
\hline & & & Oــ & \\
\hline & Papyrus E 3226 & & 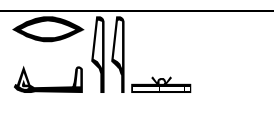 & \\
\hline shwy & $\begin{array}{l}\text { A- Louvre } \\
\text { Papyrus E } 3226\end{array}$ & $\mathrm{~Wb}, \mathrm{IV}, 10-14$ & 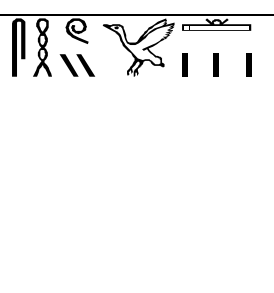 & $\begin{array}{l}\text { An arithmetic } \\
\text { expressions } \\
\text { means } \\
\text { "summary" or } \\
\text { "abbreviated" }\end{array}$ \\
\hline $\operatorname{sh} 3$ & $\begin{array}{l}\text { A-Louvre } \\
\text { Papyrus E } 3226\end{array}$ & $\mathrm{~Wb}, \mathrm{IV}, 232$ & I & $\begin{array}{l}\text { An arithmetic } \\
\text { expressions } \\
\text { means } \\
\text { a memorandum } \\
\text { or a total } \\
\text { statement it } \\
\text { been reported in } \\
\text { these forms }\end{array}$ \\
\hline
\end{tabular}

${ }^{1}$ Sherif, A collection of administrative hierarchies in the Egyptian Museum, 13.

2 James Henary, The Hekanakht Papers and other Early Middle Kingdom documents, (Newyork: Metropolitan Museum 1962), 52-53, pl.10, 2- 3.

${ }^{3}$ Mounir Magally, Notion de comptabilite à propos du papyrus E3226 du Musee du Louvre (Cairo: Institut français d'archéologie orientale1977), 54, 61- 63. 


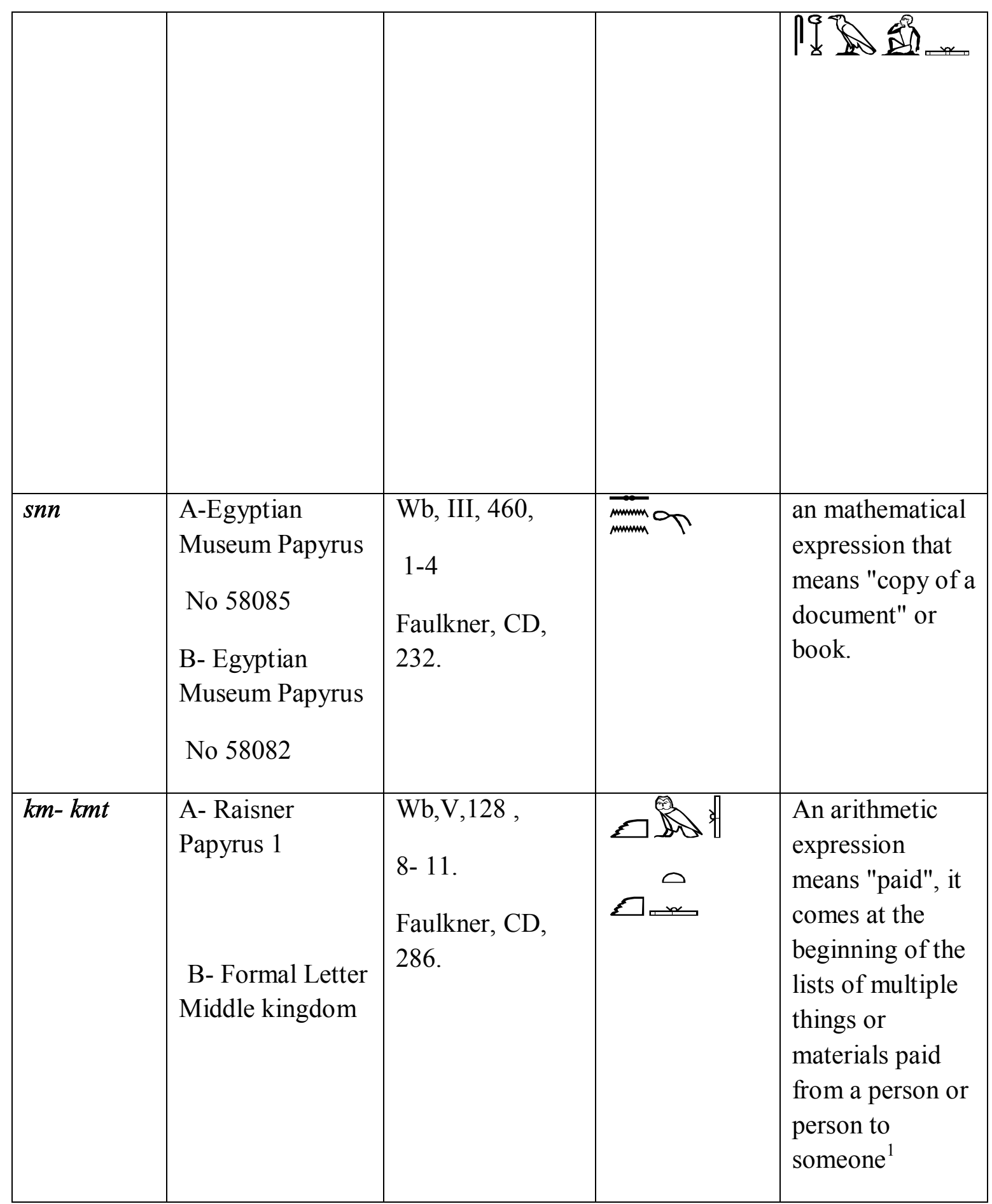

${ }^{1}$ Fayza Haikal, "A Letter of the Middle Kingdom", JAE 70 (1984-1985): 314. Pap.Reisner, I, 83. 


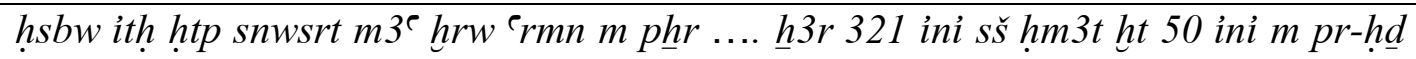
rdi $p h r . . .15$ m im-s3 $n$ hpr k3t rn.f snb

The emulators (who) are conducting the stones: Hetep Snosert Sadiq say 25 pieces were placed and remained in the barn ... 321 pouch brought from the salt county swamps 50 stick brought from the treasury department and given to the barn ... 15 from im-s3 to business manager seneb

Simpson commented on term $h s b w$ is that it sometimes describes the type of workers who prepare for work assignments, and an expression $h s b w m 3 t \&$ \& Describes the additional workers of the list, or means the workers of the new list, and in any case, the word $h s b$ as an act directly refers to a statistic as previously or calculate (arithmetic list) as read ${ }^{1}$ :

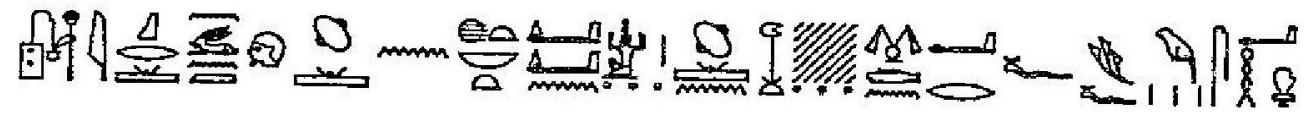

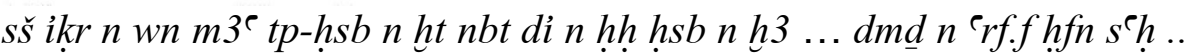

The excellent writer, presented the list of real account for each property, he has made hundreds of thousands, and counted hundreds of all his plants and tens of thousands (for) nobles...

It also expresses the enumeration of individuals as $\operatorname{read}^{2}$ :

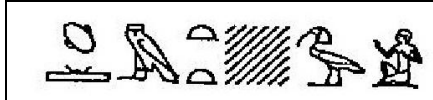

hsb $m 3 h$

Counting of the soul

Or farmland or Cattles $^{3}$ and their own titles as read ${ }^{4}$ :

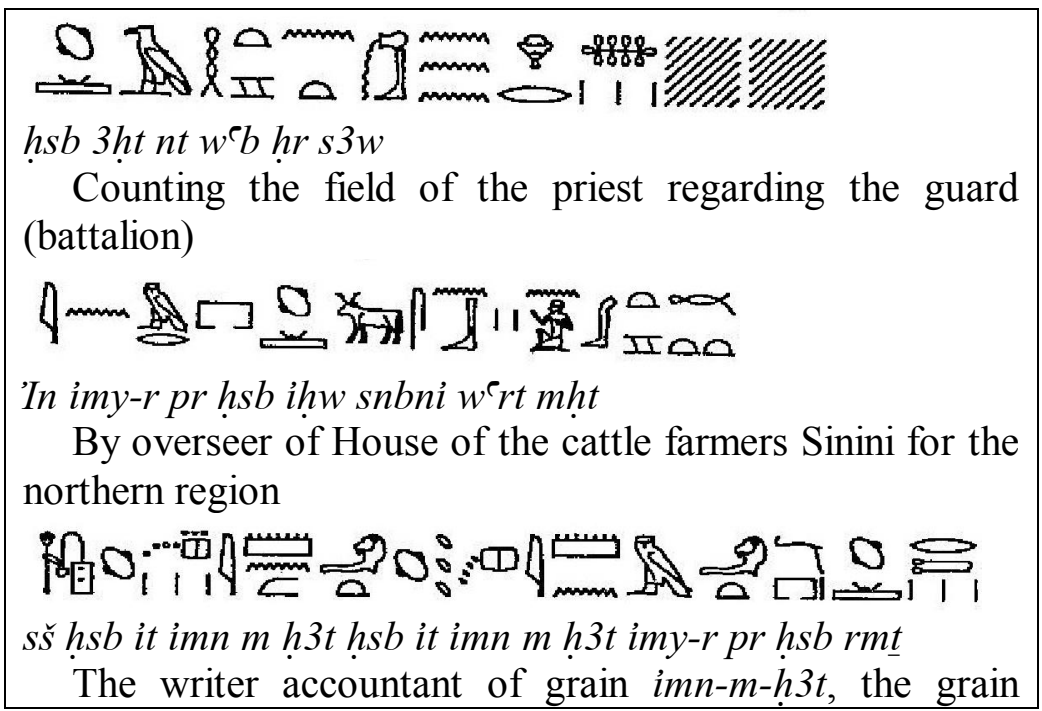

\footnotetext{
${ }^{1}$ CG 583, 5 = L. Borchardt, 'Statuen und Statuetten von Konigen und Privatleuten', Bd, I ( Berlin: Museum von Kairo, 1919), 135.

${ }^{2}$ Urk, V, 105.

${ }^{3}$ Amer, "Census of Cattles in ancient Egypt", 92.

${ }^{4}$ P. Kahun- Gurob, II, PL. 12, 2, I, 52.
} 


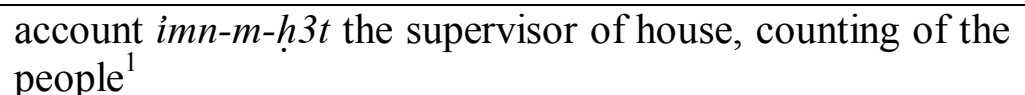

As for the counting of numbers and time, they are received as read ${ }^{2}$ :

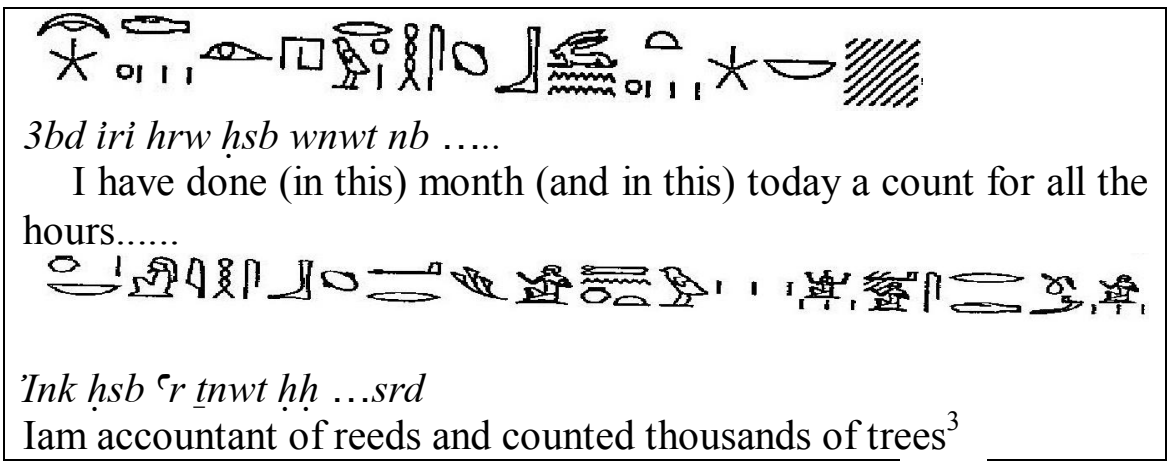

When the word $h s b$ comes with the word $t p$ or arithmetic list as read ${ }^{4}$ :

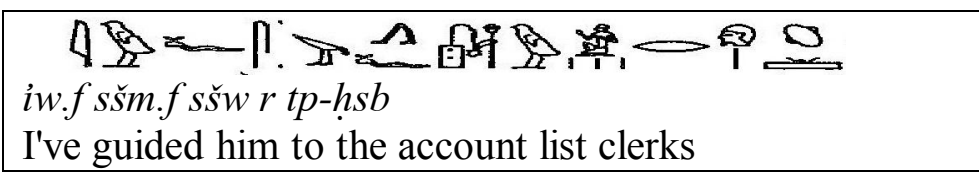

\section{Chet}

This term expresses the total amount of delivery and often relates to the quantities of grain and always comes in the charts of the charts of the hieratic charts ${ }^{5}$. As for the examples of ${ }^{\top}{ }^{\complement}$ found in the era of the Twelfth Dynasty - the Middle Kingdom, the thirteenth Dynasty where the term is mentioned in the Kahun Papyrus as read ${ }^{6}$ :

$$
\begin{aligned}
& \text { Concerning counting of thousand } \\
& \text { che } h 3
\end{aligned}
$$

In the seventeenth Dynasty, in the Rind Mathematical Papyrus, in addition to most of the records of the new kingdom era and also in the Moscow sporty papyrus, and in the texts of the new kingdom, ' $h^{\top} t$, ${ }^{\top} h^{\top}$ meaning (amount, quantity, number) as read in Boulaq $18^{7}$ :

\footnotetext{
${ }^{1}$ Urk, IV, 105, 10- 13.

${ }^{2}$ Norman Davies, The Rock Tombs in EL-Amarna, I (London: Archeological survey of Egypt, 1903), PL. PL. 36.

${ }^{3}$ CG 583, P.137, 3.

${ }^{4}$ Urk, IV, 20, 1.

${ }^{5}$ Megally, Notion de comptabilite, 56- 57.

${ }^{6}$ Kahun- Gurob, II , 119.

${ }^{7}$ Megally, Notion de comptabilite, 57.
} 
m-h̆t hh3wt $m$ tpy 3ht sw 153 bd 3 šmw sw 15 mhtri $n$ tnw $n$ rnpt rht $n$ dkr(w) $m$ rnpt hh hfn nsw bity $n b t 3 w y$

accompanying the list of properties in the first month of the flood season, Day 15, and in the third month of the flood season, Day 5, due to each year, a list of offerings for millions and hundreds of thousands of years (coming) of the King of Upper Egypt and the Lower Master of the double Earth ${ }^{1}$

Sometimes it means "list" or "statement" with payment information as in the second Kahun papyrus as read ${ }^{2}$ :

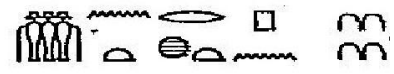

$$
\begin{aligned}
& \text { hnt rht pn } 4000 \\
& \text { [Paid] of this statement } 4000
\end{aligned}
$$

For example, you may mean; (1) a list for delivery or deposit ${ }^{3}$ as $\mathrm{read}^{4}$ :

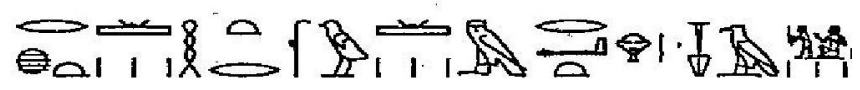

rht htrw $m$ rdi.t hr sm3

Annual list of taxes (which) give to the people

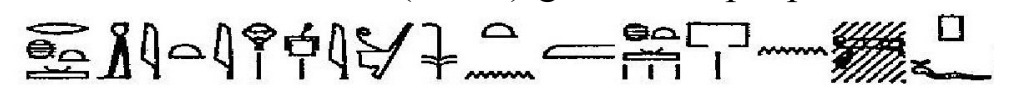

rht ini hr $-s 3$ in nswt $m$ ht pr $n$ hrww pf

The list (which) was brought by the king after that of the house of this enemy ${ }^{5}$

As well as in Kahun Papyrus as read ${ }^{6}$ :

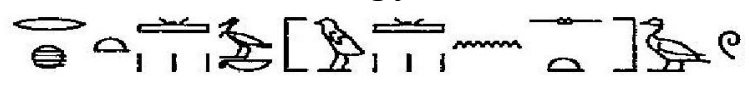

rht b3kw $n$ st 100

List of duck production 100

(2) List of cereals or legumes ${ }^{7}$ as read $^{8}$ :

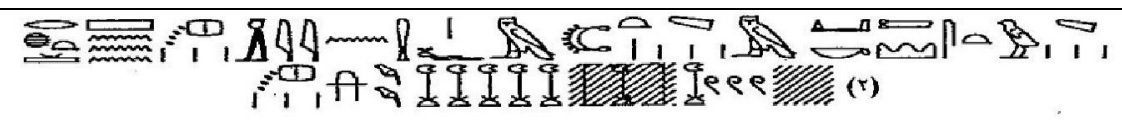

rht šmw ini $n$ hm=f $m$ `hwt mdik stw hk $3 t$ h $3 r$ 207, 300

The harvest list (which) was brought by His Majesty from the fields of Megiddo: four times the $h k 3 t$ of grain 207,300

\footnotetext{
${ }^{1}$ KRI, I, 90, 14-16.

${ }^{2}$ P.Kahun- Gurob, II, Pl.21, 31, I, 54.

${ }^{3}$ Ferdric Griffith, The Petrie Papyri: hieratic papyri from Kahun and Gurob; principally of the Middle Kingdom, Band I (London: Bernard Quaritch 1897) 18 \& Band II (London: Bernard Quaritch, 1898), PL. $8,44$.

${ }^{4}$ Kahun- Gurob, II, Pl. 21, 30.

${ }^{5} \mathrm{Urk}, \mathrm{IV}, 664,17$.

${ }^{6}$ Kahun- Gurob, II, Pl. 8, 44, I, P. 18.

${ }^{7} \mathrm{~Wb}, \mathrm{II}, 448,15$.

${ }^{8}$ Urk, IV, 667, 13- 14.
} 


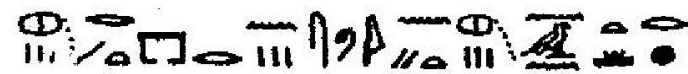

rht $n 3$ it nty iw $=$ sn $r$ prt

List (amount) of grains that will be (used) as seeds

The expression has been used $\diamond \Delta \theta_{0}$ to know" and means (list) at the beginning of some statistical lists since the second half of the new kingdom ${ }^{3}$ in one of the appendices as read ${ }^{4}$ :

\section{\&PA \\ r rdit $r h=t w 3$ ht $n b t$ idi nht-m-mwt $n$ hri \\ make it known (list) of him all things given by Nakhm to mother of Huri}

The word $r h t$ is included with the word $h s b$ in one paragraph of Papyrus 18, where $h s b$ describes the arithmetic form or the balancing process, while $R h t$ refers to quantities of different materials as read ${ }^{5}$ :

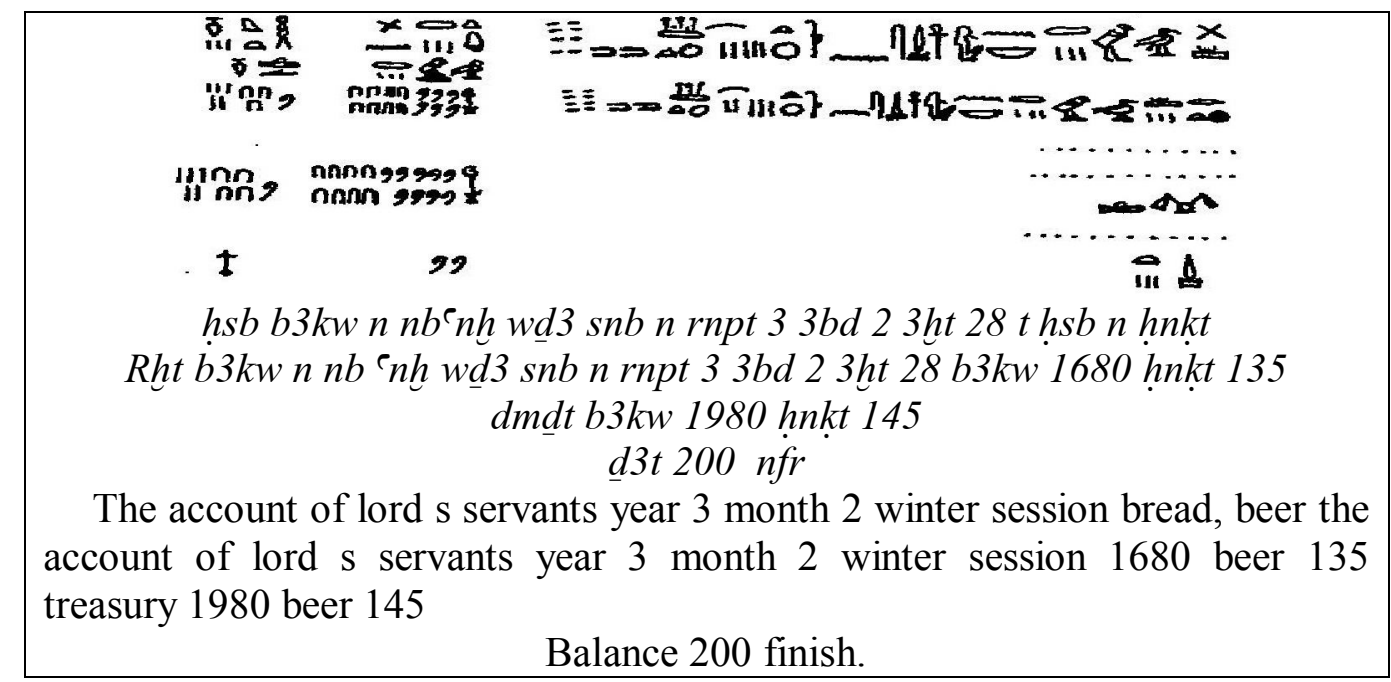

\section{Imy-rn.f}

Means a list of names or literally (name - by name) ${ }^{6}$ and was often used as a list of lists to record or name the names of the workers assigned to a work $^{7}$, as mentioned in the initial Raisner papyrus as read ${ }^{1}$ :

\footnotetext{
${ }^{1}$ P. Reisner, II, pl. 6 a, 1.

${ }^{2}$ Egyptian Museum Papyrus No. 85072 (Public Record), First line.

3 Jroslav Cerny, Alan Gardiner, Hieratic Ostraca (Oxford: Griffith Institute at the University Press, 1957); pl. xviii , 3, 1; XXI, 2,1; LXXII, 1, rt, 1.

${ }^{4}$ Sherif, "A collection of administrative hierarchies", 12.

${ }^{5}$ Sherif, "A collection of administrative hierarchies", 10.

${ }^{6}$ Abd el- Mohsen Bakir, Egyptian Egistolography (Cairo, Bibliotheque d' Etude 48, 1979), $67 \mathrm{f}$.

${ }^{7}$ Sherif, "A collection of administrative hierarchies", 12.
} 


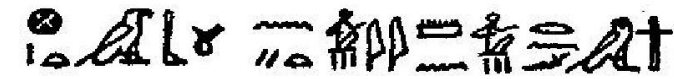 \\ Imy-rn=f mny nty $(\mathrm{m})$ Gbtyw \\ List of workers of mny (from) Qeft}

This expression is closely related to the census and census of the population, whether they are workers, soldiers or slaves, as they are listed in the "wb" (list of names) as translated by Faulkner ${ }^{3}$, the list of names as in the Kahun Papyrus as read ${ }^{4}$ :

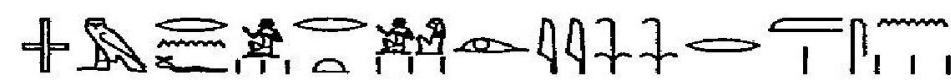 \\ Imy - rn.firi nn r-gs.sn}

List the names of individuals who have done those things to them....

As in the Heiratic texts of the British Museum No. 5646 as read ${ }^{5}$ :

$$
\begin{aligned}
& \text { List of names of things for this man } \\
& \text { Imy - rnf } n \text {. }
\end{aligned}
$$

Which come as a note in Anastasi Papyri IV as read

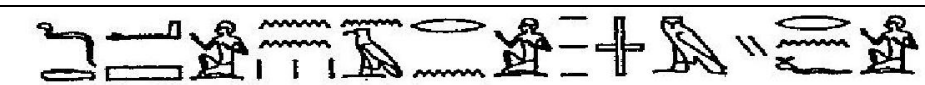

dd s3 n.n n3 rnw imy $-r n . f$

Read the names aloud from the contact list

It is clear from this text that this expression refers to the process of calling on the names of soldiers or workers, where he says or calls the commander or observer on the name of the person responds to the person who was calling for his name, and this procedure was intended to make a census of workers or soldiers or prove their Presence or absence, and when this term is associated with a word $7 "$ iri by this form:

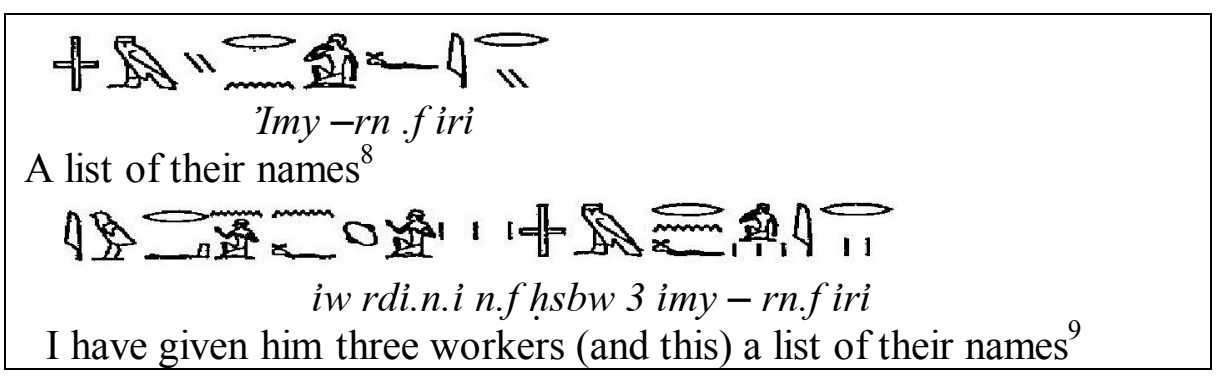

\footnotetext{
${ }^{1}$ P. Reisner I, PL. 2.

${ }^{2} \mathrm{~Wb}, \mathrm{I}, 74,15$.

${ }^{3}$ CD, P. 19.

${ }^{4}$ P. Kahun- Gurob, II, PL.13, 1, I, 32.

${ }^{5}$ ZAS 6 (1868), 41.

${ }^{6} \mathrm{P}$. Anstasi, V, 25, 8.

${ }^{7} \mathrm{~Wb}, \mathrm{I}, 74,16$.

${ }^{8}$ P. Kahun- Gurob, II, PL. 30, 32, I, 73.

${ }^{9}$ P. Kahun- Gurob, II, PL. 30, 32, I, 73.
} 
It is also clear from previous texts that the expression imy -rn.f is closely related to the conduct of the census process, whether it is a population, a worker or a soldier ${ }^{1}$ Haning $^{2}$ referred to it as a book of names or a directory of names, as in the Ryzner papyrus II, as read ${ }^{3}$ :

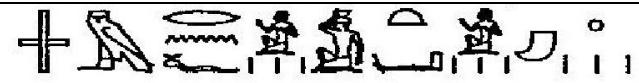

$$
\begin{aligned}
& \text { 'Imy -rn.ff3ti whmt }
\end{aligned}
$$

It is actually associated with shni and this term literally means "whose name is ...." i.e. it is used as a descriptive name or as a sign of existence, and Dominique valbelle ${ }^{4}$ states that this combination appeared from the dynasty 12 meaning sign or restrict. Scientists confirm that this expression means a list of names or a directory of names as Lepsius ${ }^{5}$ stated that this expression came as the title of the list of names.

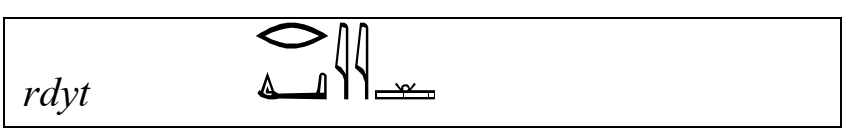

The old Egyptian used to start recording his statistics and accounts, especially those that are recorded for official operations carried out by certain departments and by officials responsible for them in terms of the beginning of the statistical registration and refers to the statistical process in terms of nature and vary according to the difference and also the difference of registration and may be the most famous words are $r d y t^{6}$

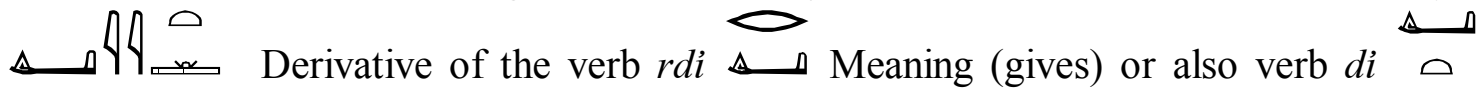
The Term $r d y t$ is mentioned in many texts ${ }^{7}$ and refers to a material that is statistically recorded as being given by one part to another part ${ }^{8}$.

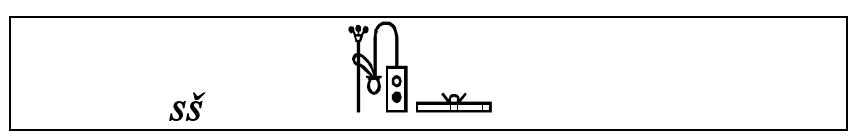

It means a written document and is translated when it is presented in a statistical address with an arithmetic document or a list as it appears in the papers of Heka Nakht as read ${ }^{9}$ :

\footnotetext{
${ }^{1}$ Amer, "Census of Cattles in ancient Egypt", 113.

${ }^{2}$ Haning, Wb, 1434.

${ }^{3}$ P. Reisner, II, H3, P1. 11 A, 31.

${ }^{4}$ Dominique Valbelle, Jonviv Hoson, State and Institutions in Egypt since the Pharaonic age to the Roman Emperors (Cairo: Dar al- Fikr, 1992), 113.

${ }^{5} \mathrm{LD}, \mathrm{III}, \mathrm{BL}, 12$, c.

${ }^{6}$ Eric Peet, "The Unit of Value Saty in papyrus Boulaq II" , Melanges Maspero I (1935): 188, irt; Megally, Louvre E 3226, Passim; Schafik Allam, Hieratische Ostraka und Papyri aus der Ramessidenzeit (Tübingen, 1973 ) 74-75.

${ }^{7}$ Sherif, A collection of administrative hierarchies, 13-14.

${ }^{8}$ Sherif, A collection of administrative hierarchies, 13.

9 Amer, "Census of Cattles in ancient Egypt", 68.
} 


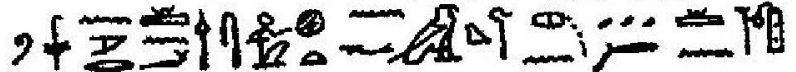 \\ š́ $n$ it mhy $n$ hk3-nht swd $. n=f n$ mry-sw \\ The Corns list of Heka Nakhth Which delivered to mry-Sue}

As for concerning the terms used on the census process were found as follows:

\begin{tabular}{|c|c|c|c|c|}
\hline Term & Texts & Source & Transcript & Remarks \\
\hline$I p$ & $\begin{array}{l}\text { A- Raisner } \\
\text { Papyrus I } \\
\text { B- Anstasi } \\
\text { Papyrus I } \\
\text { C- Anstasi } \\
\text { Papyrus IV } \\
\text { E- CG Papyrus } \\
\text { 20025 } \\
\text { F- Sallier } \\
\text { Papyrus I }\end{array}$ & $\begin{array}{l}\text { Wb ,I, } 66 \\
\text { CD, } 16 . \\
\text { Hannig,Wb, } \\
1554 . \\
\text { LD, } 29 . \\
\text { CDD, I, } 89 \\
\text { Er.Glossar.28 }\end{array}$ & 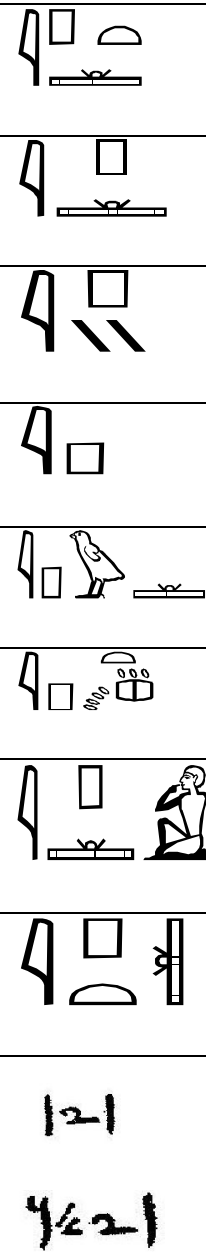 & 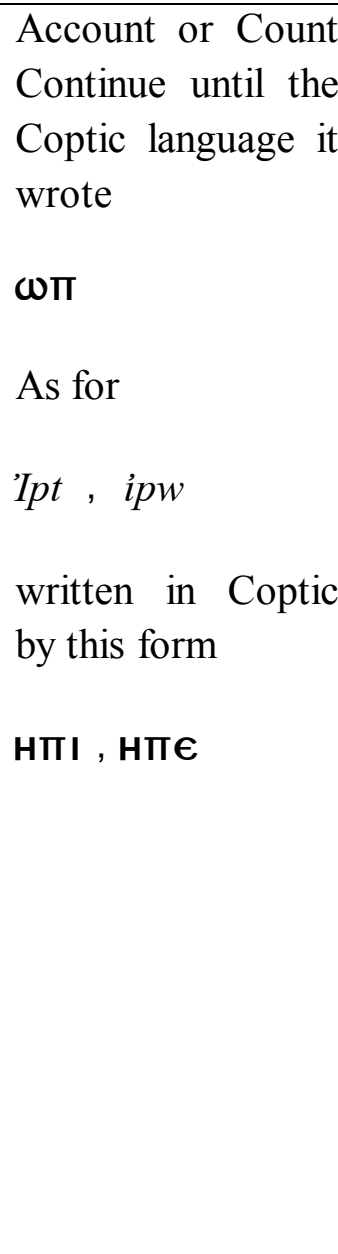 \\
\hline$\underline{t} n w t$ & $\begin{array}{l}\text { A- Harris } \\
\text { Papyrus I } \\
\text { B- Ostraca CG } \\
42185 \\
\text { C- Inscription } \\
\text { one of Barcha } \\
\text { Tombs }\end{array}$ & $\begin{array}{l}\mathrm{Wb}, \mathrm{v}, 379,5-7 \\
\mathrm{CD}, 305 .\end{array}$ & $\begin{array}{c}\infty \\
\infty \\
\infty \\
\infty\end{array}$ & $\begin{array}{l}\text { Counting } \\
\text { Quantity } \\
\text { Numerical amount }\end{array}$ \\
\hline
\end{tabular}


The concept of Account-Lists in Ancient Egypt

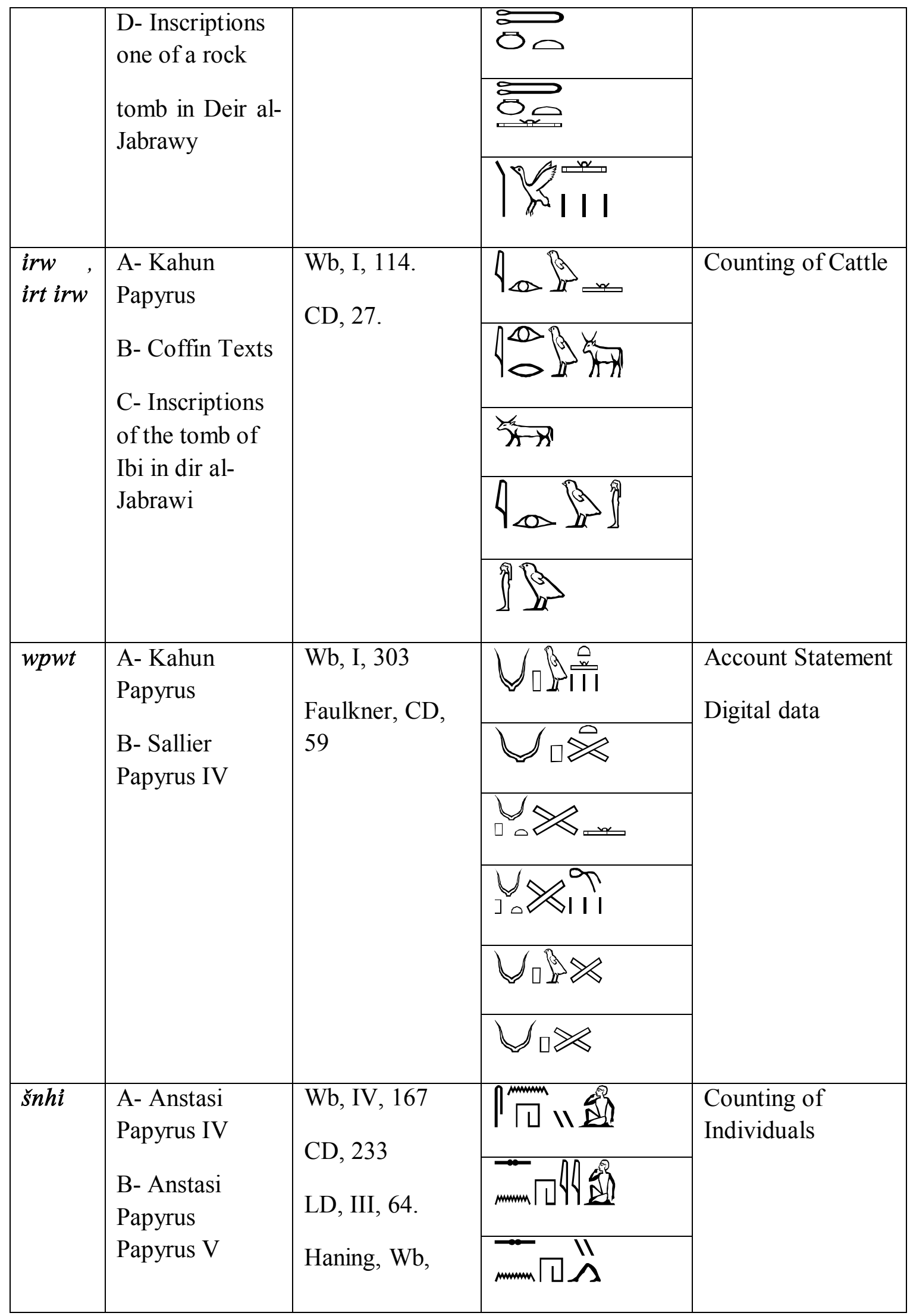




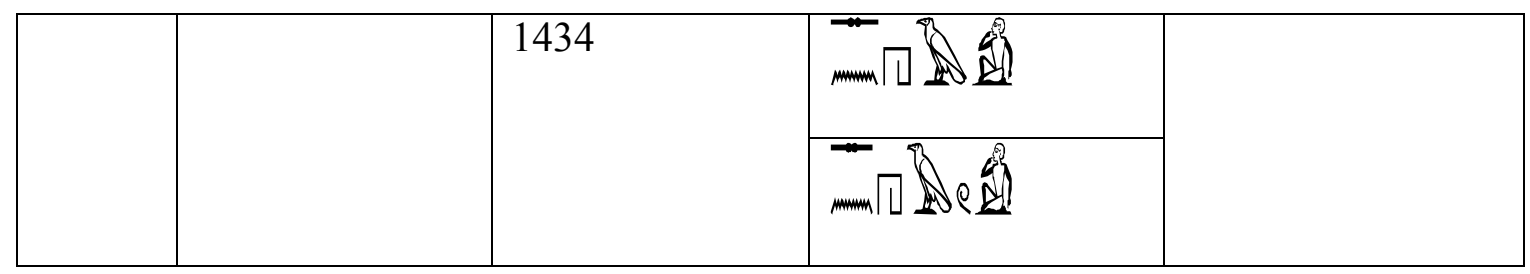

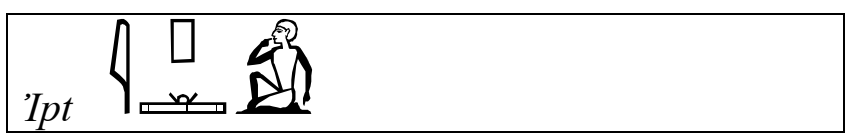

The express ipt is derived from the verb ip and means counting or estimating. Doxey ${ }^{1}$ points out that when an $i p$ is used as a noun or a noun means counting, counting, counting, counting, imposing or calculating a tax, and this verb is constant in the context of your speech The economic aspect and that the names are:

A- ip means the art or science of accounting and interpretation and also means a census or calculation of taxation.

B- Ipt means count.

When talking about ip and its derivatives ipt, ipw in ancient Egyptian texts, we find many similar examples in the second Raisner papyrus as read ${ }^{2}$ :

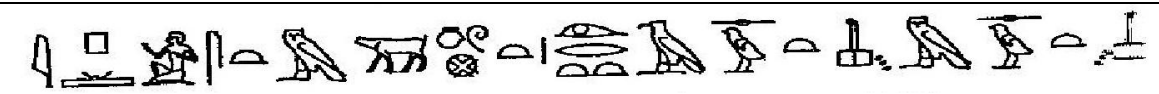

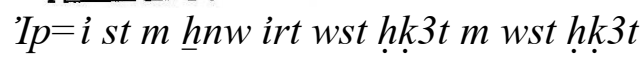

I will take it at the seat of government, and I will make weight of Heka like the weight of the new Heka

Ostraca No.CG 20025 as read $^{3}$ :

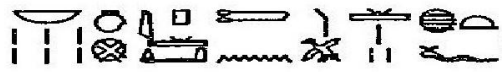

$N b$ hmnw di ip $\underline{t} n w$ ht $t=f$

The lord of Ashmonien (who) provided a census of his various

properties

Sallier papyrus I as read ${ }^{4}$ :

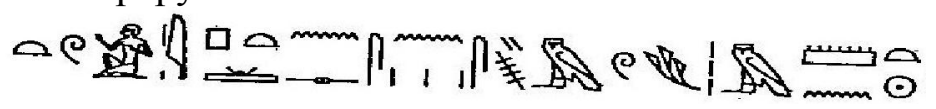

tw. $i$ ipt $n$. sn smw mnt

Count (or allocate) their grass daily

Anastasi papyrus I as we read ${ }^{5}$ :

㨁

\footnotetext{
${ }^{1}$ Denise Doxey, Egyptian Non-Royal Epithets in the Middle Kingdom : A Social and Historical Analysis, (Leiden: Boston, Brill, 1988), 178.

${ }^{2}$ Pap.Reisner, II, 21.

${ }^{3}$ CG 20025, 29- 30.

${ }^{4}$ P. Sallier, I, 4, 10.

${ }^{5}$ P. Anstasi. I, 17, 5.
} 


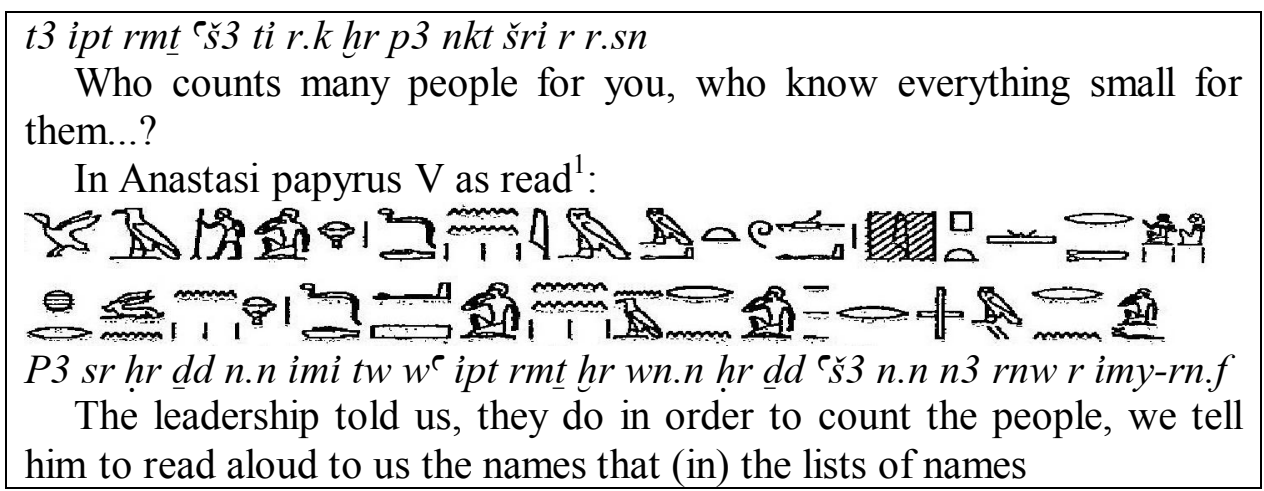

In this last example, we note the existence of ipt with imy-rn.f in one example.

The first is used for the last and last names list, as mentioned earlier, but if it is associated with the word $n s w$, it means the Royal Statistics House and also the main economic center Prepositions; And came with the letter $n$ to express the count or count or allocate something to someone as mentioned in the texts of the pyramids as $\operatorname{read}^{2}$ :

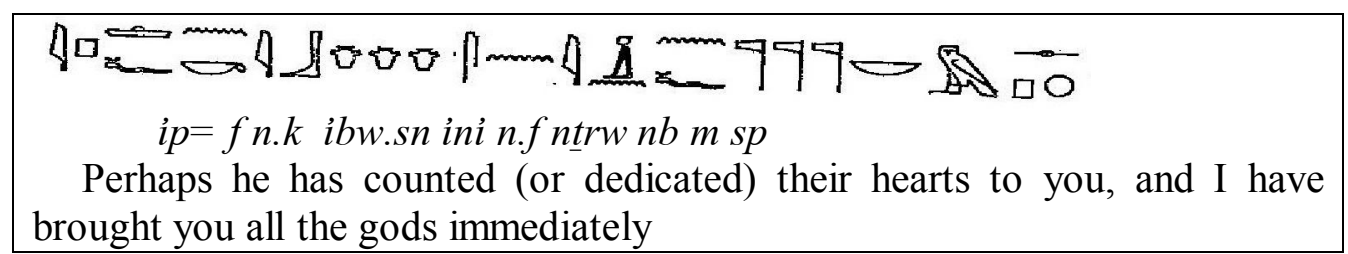

It is also used with the uppercase letter to express counting or counting on a person or a debt account as read ${ }^{3}$ :

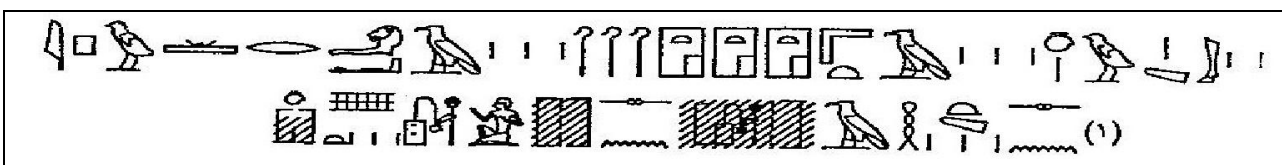

'Ipw r h3wty-` hk3w hwt knbwt nw whmw nw sp3wt š̌sn sšw 3hwt.sn

I have counted the mayors and the rulers of the villages (through) the messengers of the registrants of the territories, their books and their field accountants

It was used with $m^{-}$c preposition person $^{4}$ as read ${ }^{5}$ :

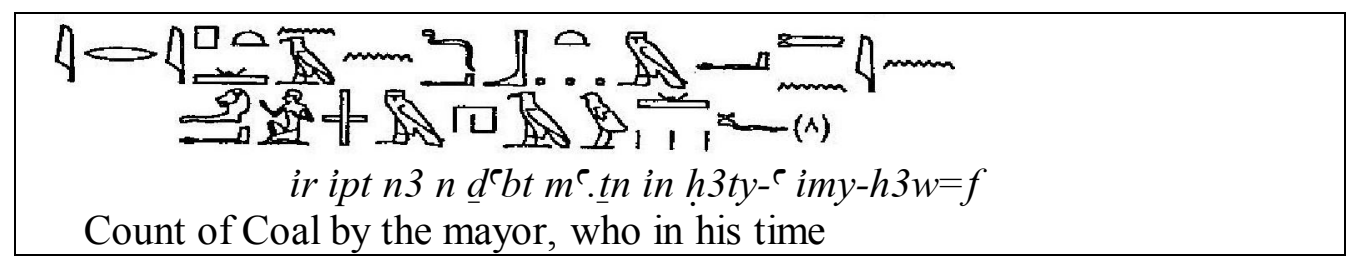

\footnotetext{
${ }^{1}$ P. Anstasi. V, 25, 8 .

${ }^{2}$ Pyr. 590.

${ }^{3}$ Urk, IV, 1129, $1-2$.

${ }^{4}$ Amer, "Census of Cattles in ancient Egypt", 77- 78.

${ }^{5}$ Fredric Griffith, The Inscriptions of Siut and Der Rifeh (London: Trubner, 1889), I, pl. 7, 294.
} 


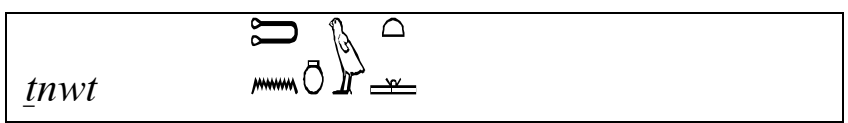

The express $\underline{t} n w t$, which means census or census, is derived from the verb $\underline{t} n w$ in terms of counting or counting ${ }^{1}$, the express $\underline{t} n w t$ came in many texts. It is noticeable that that this word was the first expression of the census and census of the country's wealth of gold and fields for the purpose of limiting and to estimate taxes on them as read $^{2}$ :

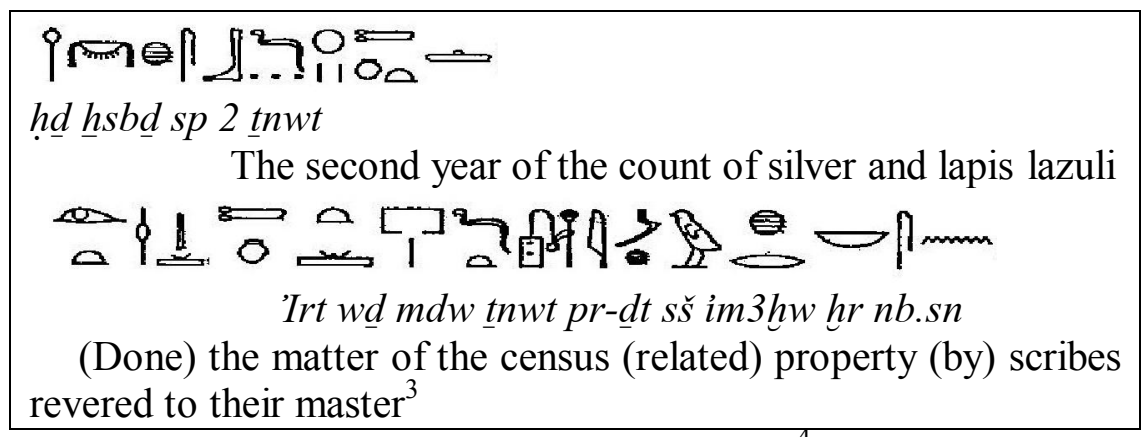

On the count of quantities or amount reported t $n w t$ as read ${ }^{4}$ :

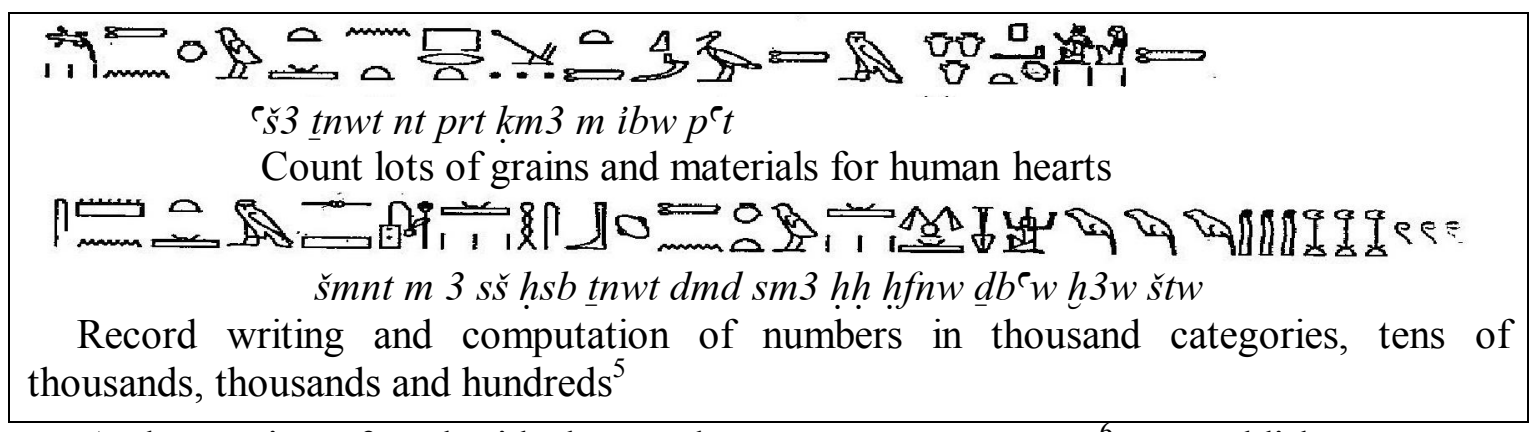

And sometimes found with the word iri to express a census ${ }^{6}$ or establish a count as $\operatorname{read}^{7}$ :

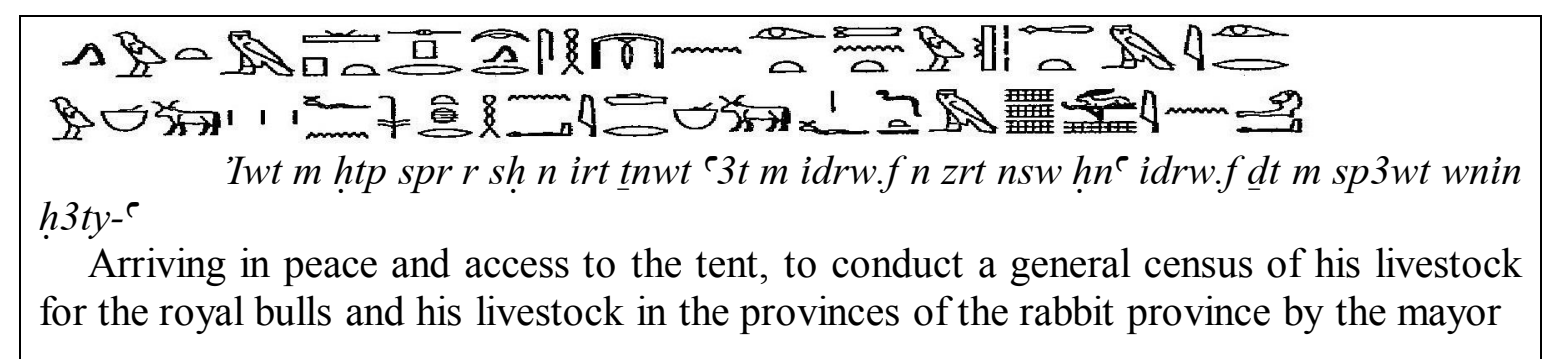

If the word thw comes in some texts followed by the word $h^{c} w$ to mean (by appearance) as read ${ }^{8}$ :

\footnotetext{
${ }^{1} \mathrm{~Wb}, \mathrm{~V}, 379,5-7$; Faulkner, CD, 305.

${ }^{2}$ Urk, I, 235.

${ }^{3}$ Davies, The Rock Tombs, PL. 8.

${ }^{4}$ Urk, IV, 249, 2- 3.

${ }^{5} \mathrm{Urk}, \mathrm{IV}, 336,5-6$.

${ }^{6}$ Amer, "Census of Cattles in ancient Egypt', 78- 79.

${ }^{7}$ Urk, VII, 52, 17- 19.

${ }^{8} \mathrm{CG} 42185,51$.
} 

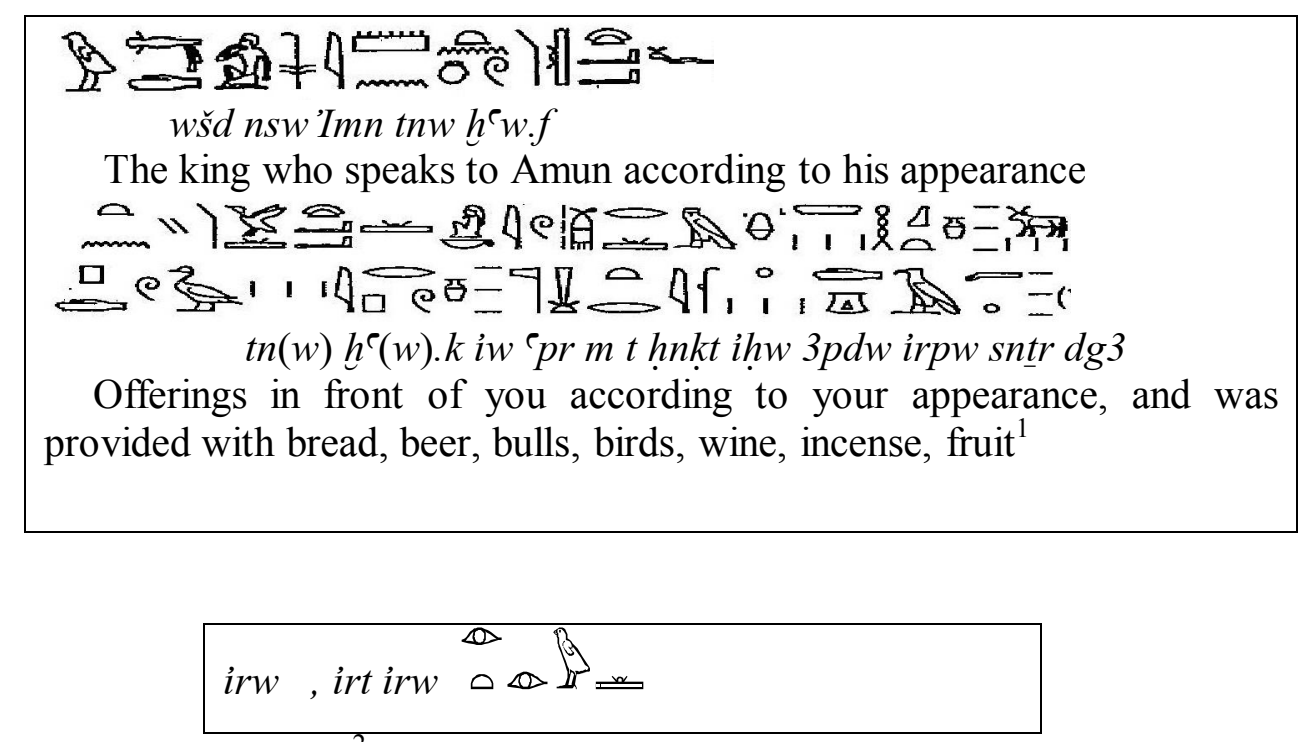

The express $i r w$ is in $\mathrm{Wb}^{2}$ meaning cattle tax, the term irt irw is translated into $w b$ in terms of the payment of cattle tax, and Faulkner translates the word irw in the livestock $\operatorname{tax}^{3}$, and there is certainly a difference between paying the tax and collecting The tax, and Anthes ${ }^{4}$ pointed out this express and translated into livestock accounts, while Montet ${ }^{5}$ that the word irw refers to the census of cattle, as read ${ }^{6}$ :

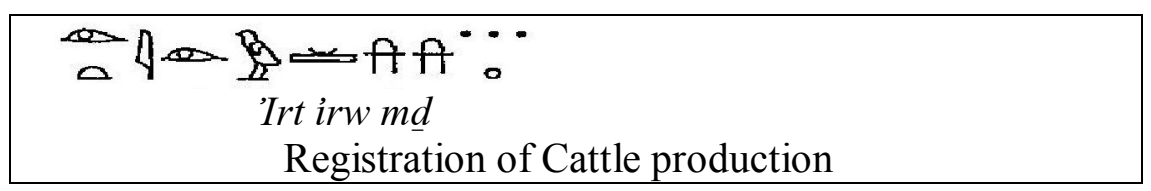

This confirms that the term irt irw means the new cattle production count, which supports the difference between $\underline{t} n w t$ and $i r w$ as two separate events or events, as stated in the text of the coffins as $\mathrm{read}^{7}$ :

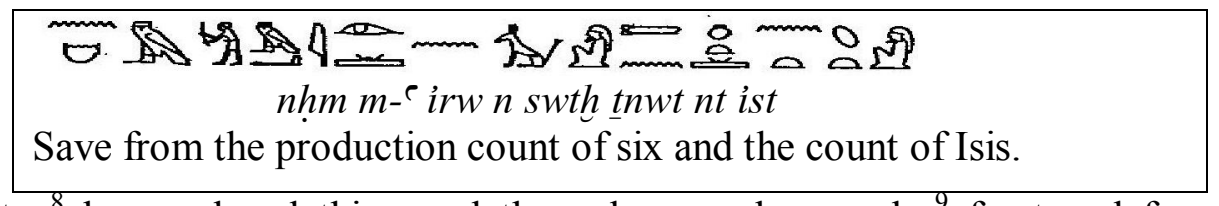

Kruchten $^{8}$ has analyzed this word through several examples ${ }^{9}$ feast and found that sometimes it is written iry, irty, or irrw, and it differs from the ad. It is possible to have a papyrus, bull, mummy or three forms of pluralism. However, if the census is a public

\footnotetext{
${ }^{1}$ P. Harris, I, 7, 4.

${ }^{2}$ Faulkner, CD, 27.

3 Amer, "Census of Cattles in ancient Egypt": 93.

${ }^{4}$ Rodulf Anthes, "Die Nominalbildungen irwt Zeremonien und irw Benehmen und Abrechung", MDIAK MDIAK 24, (1969): 34 ff.

${ }^{5}$ Pierre Montet, Les Scenes de la vie privee dans les tombes des egyptiens de l'Ancien Empire: Chapter IV, le recen sement des troupeaux (Paris: Revue belge de Philologie et d'Histoire, 1925), 128.

${ }^{6}$ Davies, The Rock Tombs, PL.VII.

${ }^{7}$ Anthony De Buck, The Egyptian Coffin Texts, II (Chicago, 1938), 157.

8 Jean-Marie Kruchten, Le décret d'Horemheb. Traduction, commentaire épigraphique, philologique et institutionnel, (Bruxelles: Editions de l'Université de Bruxelles, 1981), 85- 86.

${ }^{9}$ Amer, "Census of Cattles in ancient Egypt", 94.
} 
and official event involving the state The work of the census of irw can be considered a personal work by the individual to know his personal property or for the body in which he works, and when the supervisor of the king's cattle is doing a census of the king's irw and not the individual property ${ }^{1}$.

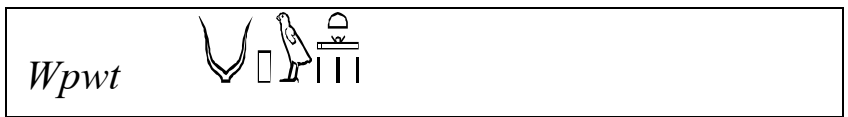

The term $w p w t$ is derived from the verb $w p$ in $\mathrm{Wb}^{2}$ which refers to information, information or data relating to arithmetic as an arithmetic term. Faulkner ${ }^{3}$ translated or $^{2}$ translated and translated it as an "inventory" while Hanning ${ }^{4}$ List as read $^{5}$ :

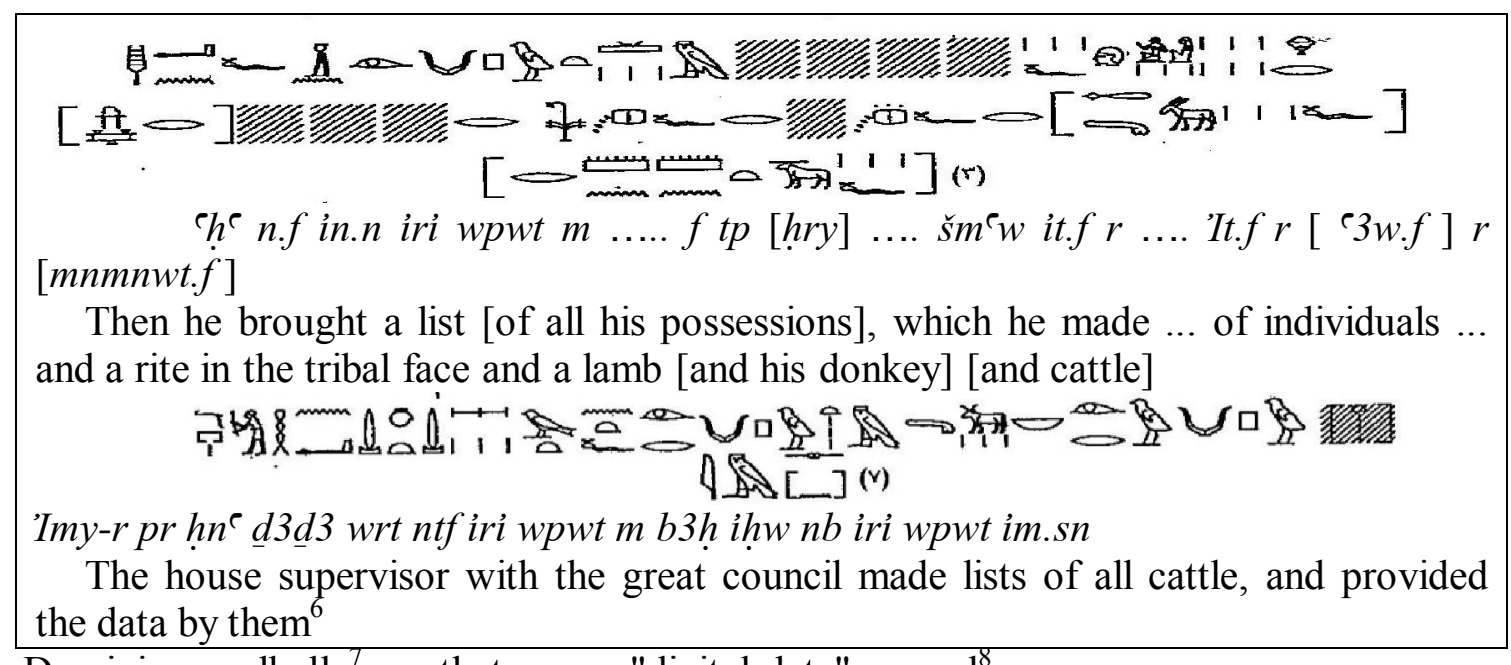

Dominique valbelle ${ }^{7}$ see that means "digital data" as read $^{8}$ :

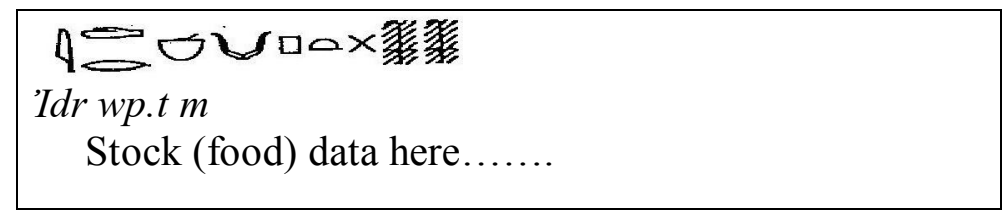

In any case, wpwt is an arithmetic expression that means a list, statement or statement that is indirect words related to the conduct of statistics and in some cases referred to the census of individuals or population ${ }^{9}$ (as in the second Kahun Papyrus) as as read ${ }^{10}$ :

\footnotetext{
1 Amer, "Census of Cattles in ancient Egypt", 95.

${ }^{2} \mathrm{~Wb}, \mathrm{I}, 303,1-2$.

${ }^{3}$ Faulkner, CD, 59.

${ }^{4}$ Hannig, Wb, 1434.

${ }^{5}$ Kurt Sethe, "Aegyptische Lesestucke", Morgenland 12 (1928): 25.

${ }^{6}$ Urk, IV, P. 1115, 6-7.

${ }^{7}$ Valbelle; Hoson, State and Institutions in Egypt, 111.

${ }^{8}$ P.Kahun- Gurob , I, 46.

9 Amer, "Census of Cattles in ancient Egypt", 97.

${ }^{10}$ P. Kahun- Gurob, II, P1. 9, 16, I, 221.
} 


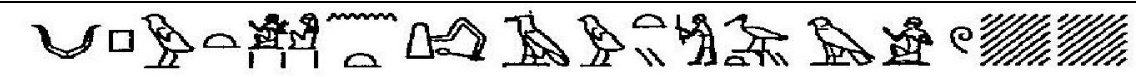 \\ Wpwt nt 'h3wty Dhwty hry 100 ......}

List of counting (individuals) House members (Relatives) Soldier Jhouti son of Hri 100

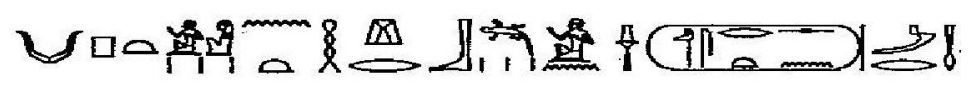

Wpwt nt hr-hb n shm sn wrst $m 3^{\complement}$ hrrw

List of counting (individuals) House of free - love of the leader of Sinusrat honest sound $^{1}$

We must point out that when wpwt comes with this customization

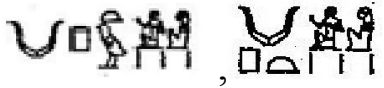

mentioned in the previous example or the meaning of individuals crowds as stated in the papyrus Salier IV as read ${ }^{2}$ :

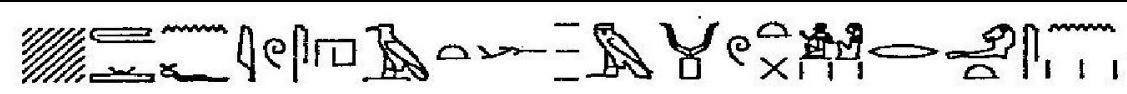

...phr n.fiw sh3wt $m$ wpwt $r$ h $3 t$.sn

For this reason, drums and crowds were knocked in front of them.....

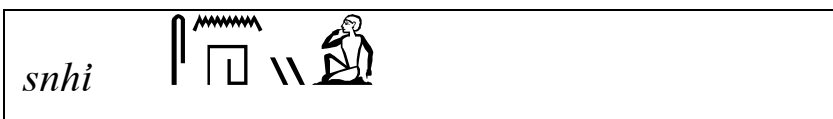

Since the twelfth dynasty, the lists of imy-rn.f names have already been associated with the "shni" (wb) ${ }^{3}$ meaning to register, bind, check and translate (Faulkner) ${ }^{4}$ to "register", "restrict" or "examine" while Haning ${ }^{5}$ mentioned as means a list or statement, statement, and Lesko ${ }^{6}$ is referred to as a census of the population. Dominique valbelle ${ }^{7}$ valbelle $^{7}$ has made it closely linked to the process of counting individuals or workers. The appearance of this act has been linked to the lists of names since the 12 th century, Registration is not just about calling or registering workers; But it also involves gathering the necessary workers and determining the nature of the tasks to be accomplished $^{8}$. šhni is mentioned in many texts in terms of "recording" or "restricting" and often relating to individuals:

\footnotetext{
${ }^{1}$ P. Kahun- Gurob, II, P1. 10, 2, I, 27.

${ }^{2} \mathrm{P}$. Sallier, IV, $1,4$.

${ }^{3} \mathrm{~Wb}, \mathrm{IV}, 167$.

${ }^{4}$ Faulkner, CD, 233.

${ }^{5}$ Hannig, Wb, 1434.

${ }^{6}$ Lesko, LED, III, 64.

${ }^{7}$ Valbelle; Hoson, State and Institutions in Egypt, 113.

${ }^{8}$ Amer, "Census of Cattles in ancient Egypt", 106.
} 
(1) - workers as read ${ }^{1}$ :

snhi n.i t3 mrwr rt iw it3.ft3 mrw iw.st m p3y.f dmit
We have registered weavers (textile workers) on the list, I
took them away, (and) they are in my city

(2) Soldiers as we read ${ }^{2}$ :

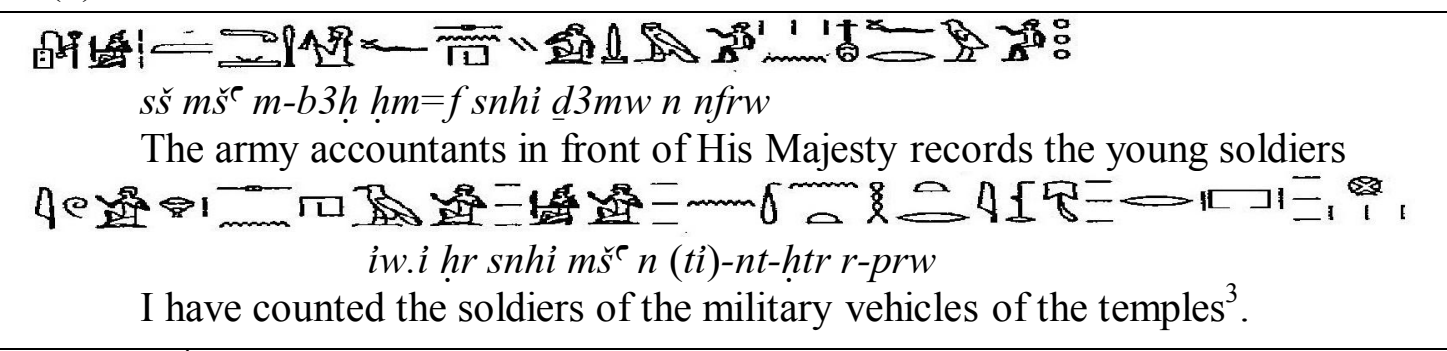

Caminos ${ }^{4}$ translated the word shni into a counting of individuals in the so-called men's assessment departments (prw hsbw rmt $)$ as read ${ }^{5}$ :

\begin{tabular}{|c|}
\hline st snhi p3y.k ms \\
This is where your army is registered \\
The word shni also came to express the review of lists or lists of names ${ }^{6}$ as read $^{7}$ :
\end{tabular}

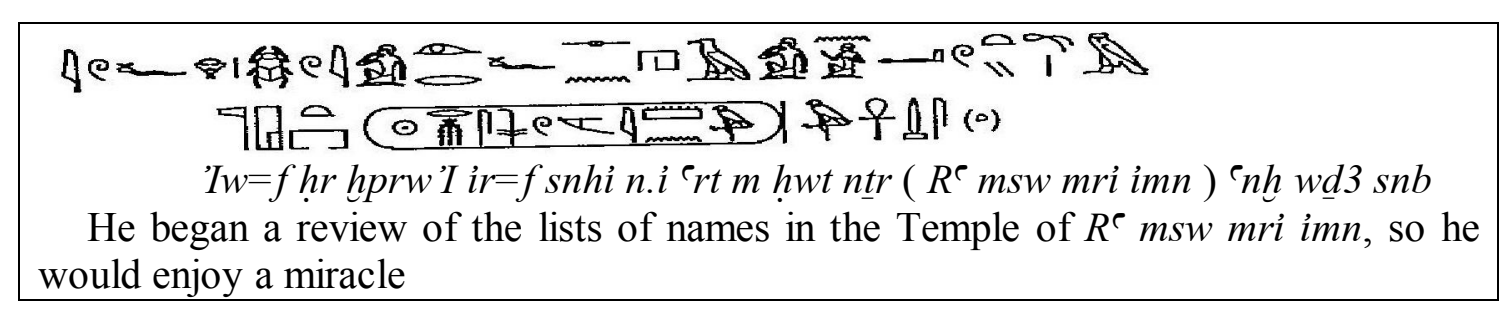

\section{Computational reporting}

The main objective of accounting is to prepare financial information about the entity. Therefore, this information is summarized in accounting reports. The most important reports that the accounting system must provide $\operatorname{are}^{8}$ :

\footnotetext{
${ }^{1}$ P. Anstasi. IV, 14.

${ }^{2}$ Urk, IV, 1006, 3- 4.

${ }^{3}$ P. Anstasi, IV, 7, 8 .

${ }^{4}$ Ricardo Caminos, "Literary Fragments in The Hieratic Script", LEM (1956): 149.

${ }^{5}$ P. Anstasi. III, 7, 5- 6.

${ }^{6}$ Amer, "Census of Cattles in ancient Egypt", 108.

${ }^{7}$ P. Anstasi. IV, 15.

${ }^{8}$ Tom Plank, Lois Plank, Encyclopedia of Accounting System, Second Edition, Volume 1(New York: Prentice Hall, 2005) 2.
} 


\section{The concept of Account-Lists in Ancient Egypt}

Financial Statements:

It is the list that controls the recording, tabulation and analysis of transactions of financial value related to a unit held in a set of books and records with a view to determining the movement of funds, goods, goods or property ${ }^{1}$. The list aims to provide financial information of all forms, whether agricultural, industrial, commercial, and service, to individual establishments or individuals. The main financial statements include ${ }^{2}$ :

(A) The budget or the statement of financial position

This list includes all accounts in the public ledger.

(B) The income statement

Includes statement of income and expenses and net profit or loss

(C) The distribution or retained earnings list.

It includes an analysis of changes in the rights of account holders.

In addition to these main lists, there are other auxiliary or sub-lists to give details of some items, which appear briefly in the basic financial statements. These lists are often in the form of tables that give details of buildings, land or equipment, inventory ${ }^{3}$

In ancient Egypt, business-related accounting books were written day by day ${ }^{4}$ in most of Egypt's ancient commercial records, known as hrw or 'rt hrw

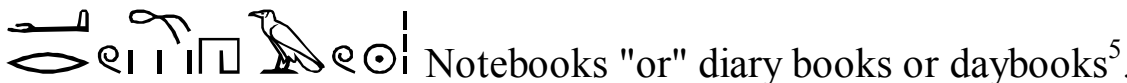

\section{Daybook}

A daily record that contains several documents for the daily administrative work and its purpose was to register directly, it was found to be a complete and systematic archival reference, and Carmona \& Ezzamel $^{6}$ called it a daily extract and any new entry added to it called due today ${ }^{7}$.

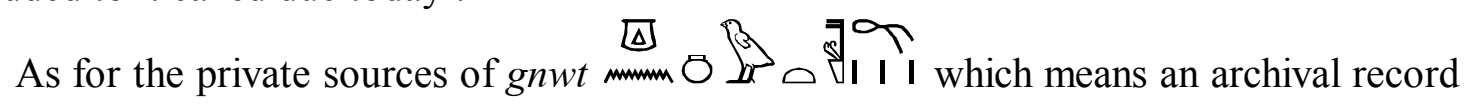
or book that gives a very early and primitive history and is neglected in the use of the Egyptian archives back to the Middle Kingdom era. The word gnwt is defined as a kind of daily record of daily business ${ }^{8}$ and written in the following forms:

\footnotetext{
${ }^{1}$ Plank, Plank, Encyclopedia, 4-5.

${ }^{2}$ Salvador Carmona, Mahmoud Ezzamel, Accounting and forms of Accountability in Ancient Civilizations: Mesopotamia and Ancient Egypt, IE Working Paper (2005), 14-18.

${ }^{3}$ Amer, "Census of Cattles in ancient Egypt", 85.

${ }^{4}$ For those types of accounts see:

Andreiw Monson, "Demotic Granary Account from the Early Ptolemaic Fayoum: P. Stanford Classics Dem 8 \& and 11", CENIM 14 (2016): 423- 434.

${ }^{5}$ Chistopher Eyre, The use of Documents in Pharaonic Egypt (Oxford :Oxford Scholarship 2013), 315

${ }^{6}$ Carmona, Ezzamel, Accounting Encyclopedia, 15.

${ }^{7}$ Carmona, Ezzamel, Accounting Encyclopedia, 15- 16.

8 Redford Donald, Pharaonic King-lists, Annals and Daybooks' a contribution to the study of the Egyptian sense of history, SSEA, Book 4 (1986), 97.
} 


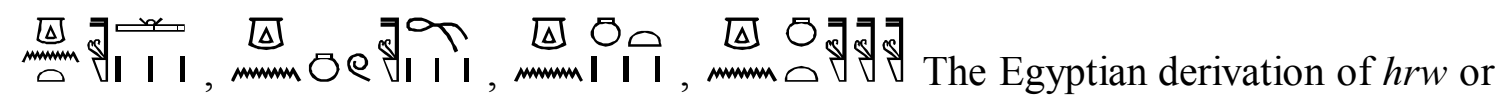
r rt hrw $\rightleftharpoons$ । । । but in the new kingdom that term was used more freely to be preferred to any type of (records) or (documents) because the traditional accounting books are working documents illustrating daily management practices but likely for a long time Term; The tables and standard lists are easy reference tools. For example, the table record of ritual equipment in the Abu Sir papyrus ${ }^{1}$ was clearly used to inspect the equipment inventory for each month when the list of priests had to change but not true for archival records ${ }^{2}$.

The Competent Group, which receives the requirements for the stores and delivers them to the author to make a note and record each individual requirement called "Departing Phyle". The registration of the inputs was done by a team called Incoming Phyle. Both teams prepare reports on delivery of roses Called Shift Delivery ${ }^{3}$.

It should be noted that the publication of individual books, which include records or accounts tend to be regular reference to the late but distinctly the tools of work for periodic accounts and not documents final statement of long-term term so far as enormous list as in the Wilbur papyrus Wilbour papyrus" "Which recorded the responsibility for revenues for grain harvesting and appears to be the annual business documents, not a record for records. It is similar to the diary books of the Roman era in the monastery of Medina, which used the tools of work for the various administrative parts of the cemetery, not the same archival documents ${ }^{4}$.

It also took the more common characteristic of "administrative papyrus" written by the right author for the daily entries of receipts, income, expenses, and daily business and again seemed to be business and not long- term reference lists 5 .

We can note in the documents of Deir Al Madinah ${ }^{6}$ that there is simple evidence of the method of writing documents for the cemetery (records, letters, reports) for the socalled workshop accounts ${ }^{7}$ that were saved or used as reference and not in those texts in in the administrative house or the private archive or The keeper of the writings, it seems to be similar to those kept by the proper scribes to write themselves either at home or at work ${ }^{8}$.

\footnotetext{
${ }^{1}$ Posener- krieger, De cenival, Abu sir (1968), 18-20: Posener- krieger, Les archives du temple funéraire de Néferirkarê- Kakaï,Vol. I \& II (Cairo: Institut français d'archéologie orientale1, 976), 125- 208.

${ }^{2}$ Eyre, The use of Documents, Plate 24.

${ }^{3}$ Carmona, Ezzamel, Accounting, 17- 18.

${ }^{4}$ Eyre, The use of Documents, 317- 318.

${ }^{5}$ Eyre, The use of Documents, 318.

${ }^{6}$ Donker van Heel, J. Haring, "Writing in A workmen village": Scribal Practice in Ramiesside DeirElmadina, Egyptologische utgaven 161, (2003) 86.

${ }^{7}$ S. Carmona \& M. Ezzamel, Accounting, 19.

${ }^{8}$ Eyre, The use of Documents, 319.
} 
It seems that the administrative books that were carried out by the appropriate clerks who could not reach the main institution took it upon themselves to convey that accurate information to the failure of the current documents for the final statement due to the sale ${ }^{1}$. The administrative letters that were dealt with by the departments on the basis of their employees and are of an administrative nature are divided into several types as follows ${ }^{2}$ : (A) Letters of order (b) Letters are reports (c) Letters exchanged between departmental staff. (D) Letters of information or communication. (E) Letters of official or friendly complaints. (F) Receipts taking the form of rhetoric.

These are the types of talks about receipts and the type of letters recorded on papyrus or ostraka, which are receipts either by taxes or receipt of a particular commodity or the payment of debt, and Mattha ${ }^{3}$ sees that the receipt of tax receipts, which took the form of letters continued on papyrus during the Ptolemaic and even Roman era.

\section{Wages records \& income of individuals}

The expression of pay in the ancient Egyptian language was as follows:

\begin{tabular}{|c|c|c|c|}
\hline Term & Text & Source & Remarks \\
\hline हु S & $\begin{array}{l}\text { A- Kahun } \\
\text { Papyrus } \\
4 \\
\text { B- Inscriptions } \\
\text { of the tomb of } \\
\text { Rakhmi Ra }{ }^{5} \\
\text { C- Resolutions } \\
\text { of a Hur- } \\
\text { Moheb }^{6} \\
\text { D-Resolutions } \\
\text { of Nuri }^{7}\end{array}$ & $\begin{array}{l}\text { Faulkner, CD,18 } \\
\text { Lesko., LD, } 127\end{array}$ & $\begin{array}{l}\text { Wage } \\
\text { Wages }\end{array}$ \\
\hline
\end{tabular}

${ }^{1}$ Eyre, The use of Documents, 320.

2 Soaad Abdel Aal, "Correspondence through Demotic Documents" (unpublished MAThesis, Cairo University, Faculty of Archeology, 1983) 56-57.

${ }^{3}$ Gerges Matta, Demotic Ostraca From The Collection at Oxford, Paris, Berlin, Vienna, and Cairo (Cairo: Impr. de l'Institut français d'archéologie orientale 1945) 9-11.

${ }^{4}$ Francis Griffith, Hieratic papyri from Kahun and Gurob principally of the Middle kingdom (London: Quaritch, 1898), pl. xv, 39- 43 ff.

${ }^{5}$ Norman Davies., The tomb of RKH-MI-RA at Thebes, Vol 1 ( New York: Metropolitan Museum of Art, Art, 1973), Pl. 56, $57,47 \mathrm{f}$.

${ }^{6}$ Kruchten, Le Decret d Horemheb, 62.

${ }^{7}$ Francis Griffith, "The Abydos Decree of Seti 1 at Nauri", JEA 13 (1927): 193- 209. 
The concept of Account-Lists in Ancient Egypt

\begin{tabular}{|c|c|c|c|}
\hline 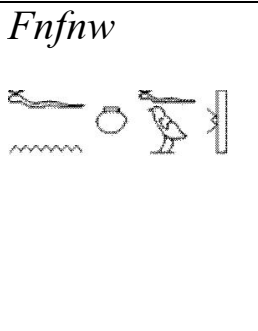 & $\begin{array}{l}\text { A- A text for } \\
\text { Rakhmi Ra } \\
\text { works with the } \\
\text { builders in the } \\
\text { Temple of } \\
\text { Amun }\end{array}$ & $\begin{array}{l}\text { Wb, } 576 \\
\text { Faulkner, CD, } 98 \\
\text { Urk, IV, 1151, } 4\end{array}$ & Wage \\
\hline $\begin{array}{l}\underline{h} s f^{-} \\
\frac{29}{D}+0\end{array}$ & $\begin{array}{l}\text { A- An } \\
\text { engraving of a } \\
\text { worker from } \\
\text { the reign of } \\
\text { Tuthmosis II }\end{array}$ & $\begin{array}{l}\text { Faulkner,CD, } 197 \\
\text { Urk, IV, 138, } 10\end{array}$ & Wage strike \\
\hline 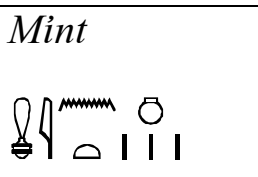 & $\begin{array}{l}\text { A- the story of } \\
\text { Snohi }\end{array}$ & $\begin{array}{l}\text { Faulkner, CD, } 104 . \\
\text { GNS, } 14\end{array}$ & $\begin{array}{l}\text { Daily fare } \\
\text { Daily food }\end{array}$ \\
\hline
\end{tabular}

\section{The linguistic aspect:}

The use of $b 3 k w$ as a typical expression as a wage means the value or price of the work practiced by man or animal ${ }^{1}$ and I have written in many forms of writing can be reviewed as follows:

And the difference between them and the word htri, which means the salary (tax estimated) mentioned in the salaries of the workers of Deir- ElMadina ${ }^{2}$ and by comparing both terms we see that the htri means the obligation to pay the salary continuously even if the person does not work or b3kw is paid as a fee in exchange for performing the work so If this is not done, do not pay the $b 3 \mathrm{kw}^{3}$.

\section{Discussion:}

The wages of workers in ancient Egypt were paid for cereals, which were used to make bread, wine or directly paid for bread ${ }^{4}$ and wine, which were the main elements of

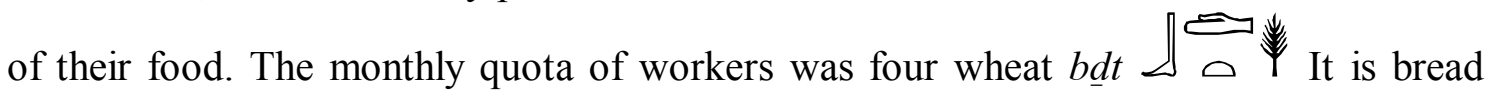
grains and one and a half outside of the barley it Barley, wine, while presidents

\footnotetext{
${ }^{1}$ Zeinab Mahrous, "Taxation in Ancient Egypt to the End of the new kingdom" (unpublished Master Thesis, Cairo University, Faculty of Archeology, 1986), 185.

${ }^{2}$ Mandiville Richard, Wage Accounting in Deir el- Medina (London United Kingdom Abercromby Press, Press, 2014).

${ }^{3}$ Mahrous, "Taxation in Ancient Egypt", 191.

${ }^{4}$ For the kinds of bread see:

Iman El Mahdi, Bread in Ancient Egypt, Egyptian General Book Authority (Cairo: Egyptian General Book Authority, 2009).
} 
and clerks receive more. The average workers and a large sector of their superiors paid them for their daily bread. They used these surplus shares to swap for other goods ${ }^{1}$.

The story of Khufu and the Magicians told us that barley was used as a grain in the payment of wages. He gave the priest Ra and the secret of the gods who helped his wife in the process of giving birth a few pints of barley as a reward for them ${ }^{2}$ :

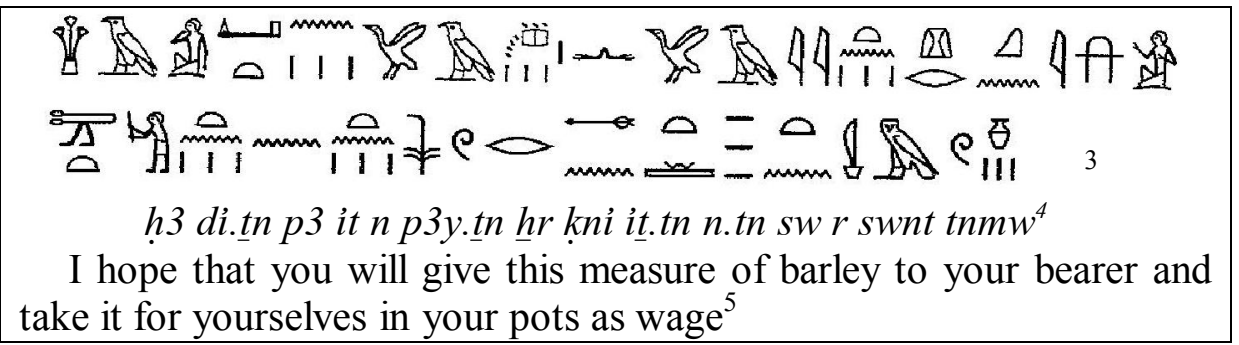

These may be meant to be used in the storage of grain and others, and must be utensils containing barley, from which beer and wine are made; Bread has also been used as a means of paying wages. In the texts of Ankh Chashniki ${ }^{6}$, he says:

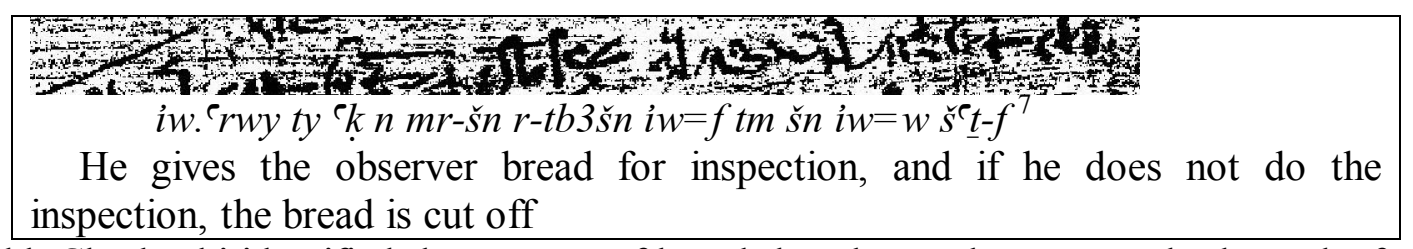

Ankh Chashanki identified the amount of bread that the worker gets and takes a loaf as a reward for him while the supervisor takes him or who leads him with two loaves because he is the highest ranking and in this he says ${ }^{8}$ :

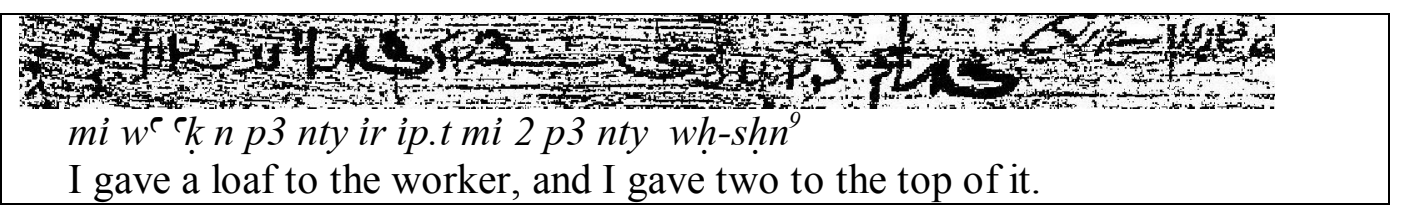

The payment of wages has an economic effect on the employer, where the worker makes more effort in his work, which results in an increase in production, says Ankh Chashanqi ${ }^{1}$ :

\footnotetext{
${ }^{1}$ Mona Saleh, "Economic Life through Ancient Egyptian Literature" (unpublished PhD thesis, Alexandria Alexandria University, Faculty of Arts, 2013), 197.

2 Saleh, "Economic Life Through Ancient Egyptian Literature", 197.

${ }^{3}$ Manely Blackman, The Story of King Kheops and the magicians: transcribed from Papyrus Westcar Berlin Papyrus, 3033 (Australia: J.V. Books, 1988).

${ }^{4}$ Mark- Jan Naderhof, Papyrus Westcar Berlin Papyrus 3033 (London: RHB 2009), 48- 49.

${ }^{5}$ Adolf Erman, The Ancient Egyptians, A sourcebook of their writings translated by blackman (London: Harper \& Row, 1978), 45.

${ }^{6}$ Robert Ritner, The Instruction of Onchsheshonqy (p. British Museum 10508) in: William Simpson, 'The 'The Literature of Ancient Egypt' (Cairo: Yale University Press, 2003), 524.

${ }^{7}$ K. Glanville, Mark Smith, Catalogue of Demotic Papyri in British Museum, Vol. II (London: trustees of of the British Museum, 1955), 54-55, Plate 24.

${ }^{8}$ Ritner, The Instruction of Onchsheshanqy, 5, 23.

${ }^{9}$ Glanville, Catalogue of Demotic Papyri in British Museum', Vol. II, 50- 51, Plate 22.
} 


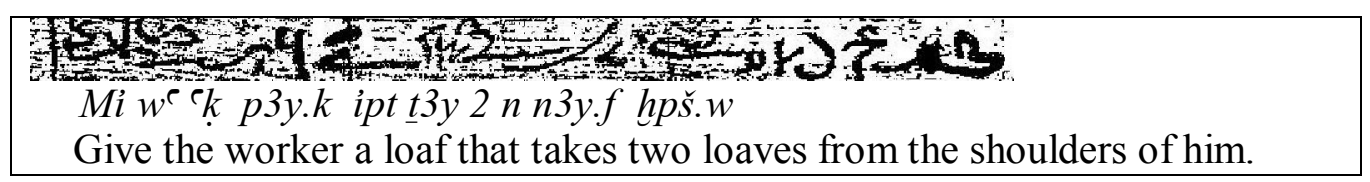

The standard wage in the real economic life of the simple laborer was ten kilos of bread, along with the equivalent of about 20 bars of beer a day, the lowest wage possible, while the highest wage was twice the wage of the worker ${ }^{2}$.

\section{Wine as wages for workers:}

Wine was part of the wages of soldiers and farm workers and there is a reference in O. Egy. Mus. No. 25504 attributed to the seventh year of the reign of Merneptah, which we know that 50 bottles of wine were allocated to the workers of Deir-Elmadina ${ }^{3}$, An account of the goods and supplies of the vine growers where he wrote, "Delivery of bread to vine growers daily ${ }^{4}$.

These wages have helped to buy goods or barter in the consumer goods markets outside the official system, thus enabling the individual to pay his needs through paid work ${ }^{5}$.

In any case, there were complaints made especially in the failures of the delivery of wages, the appropriate administrative conditions can supply the quantity of grain already, but the wages of other goods were irregular, which called for workers representatives to look at the administrative documents and provide information by tracking them and then highlighted the accounts Annual accounts of those receivables ${ }^{6}$ preserved in the Turin papyrus No. $1903^{7}$.

In that regard, he found many complaints ${ }^{8}$, which spoke of a lack of income levels of individuals, including official and friendly in what is now known (strike action).

\section{Tax receipts:}

The tax, as defined by Janssen ${ }^{9}$, is a contribution imposed by the State on its nationals of a specific nature. The tax is paid by the State to fulfill its obligations to its nationals, whether at home or abroad.

\footnotetext{
${ }^{1}$ P. Walcot, "Hesiod and The Instruction of Onchsheshonqy", JNES 21 (1962): 216 (22/19).

2 Saleh, "Economic Life Through Ancient Egyptian Literature", 198.

${ }^{3}$ O. Egy. Mus. No. 25504

${ }^{4}$ Hamada, "A Stela from Manshiyet es-Sadr", ASAE 38 (1938): 223.

${ }^{5}$ Saleh, "Economic Life Through Ancient Egyptian Literature", 198.

${ }^{6}$ Eyre, The use of Documents, 320.

${ }^{7}$ The papyrus of Turin is a papyrus written by the writer (Amon- Nacht), which scientists called the Turin papyrus strike and talk about the workers' strike during the reign of Rameses III and you see:

Pascal Vernos, Affaires et Scanddales sous les Ramses, le crise des valeurs dans l'Egypte du Nouvel $\begin{array}{lll}\text { Empire } & \text { (Paris: } & \\ \end{array}$ Jac Janssen, "A Twetieth- Dynasty Account Papyrus (Pap.Turin, No.cat. 1907/8)", JEA 52 (1966): 81- 94.

${ }^{8}$ Abdel Aal, Correspondence through Demotic Documents, 77.

9 Jac Janseen, "Prolegomna to the study of Egypt economic History During the New kingdom", SAK 3
} 
In the modern sense, they are reports on the amount of money imposed by governments on activities, expenses, jobs and income of individuals or enterprises in order to obtain financial support for the services provided ${ }^{1}$.

As for taxation in ancient Egypt, it represents an important aspect of economic life as it represents one of the sources of state resources. It also reveals the extent to which the administrative administration has the ability to manage and regulate the economic aspects and taxes ${ }^{2}$.

\begin{tabular}{|c|c|c|c|c|}
\hline Tax & Text & Source & Category & Remarks \\
\hline$(\check{s} m s w h r, \underline{t} n w t)$ & $\begin{array}{l}\text { A- Palermo } \\
\text { Stone }^{3} \\
\text { B- Queen } \\
\text { Abbott } \\
\text { compartment } \\
\\
\text { C- Inscriptions } \\
\text { of the Temple } \\
\text { of King Neusar } \\
\mathrm{Ra}^{5}\end{array}$ & $\begin{array}{l}\mathrm{Wb}, \mathrm{IV}, 485, \\
4-5 \\
\mathrm{~Wb}, \mathrm{~V}, 379, \\
5-7\end{array}$ & General Tax & $\begin{array}{l}\text { Those terms } \\
\text { are two equal } \\
\text { events that } \\
\text { serve the same } \\
\text { purpose as the } \\
\text { counting }\end{array}$ \\
\hline $\begin{array}{l}(\text { irw) } \\
0 \Longleftarrow \ldots \ldots\end{array}$ & $\begin{array}{l}\text { A- Inscriptions } \\
\text { of the tomb of } \\
\text { Sennab }^{6} \\
\text { B- Inscriptions } \\
\text { of the Tomb of } \\
\text { Iby } \\
\text { C- Wehem- Ka } \\
\text { Tomb }^{8}\end{array}$ & $\begin{array}{l}\text { Wb, I, 114, } \\
4-5 \\
\text { Faulkner, CD, } \\
27\end{array}$ & Cattle Tax & $\begin{array}{l}\text { literally } \\
\text { In effect and } \\
\text { thus refers to } \\
\text { the product or } \\
\text { production of } \\
\text { cattle }\end{array}$ \\
\hline
\end{tabular}

(1974): 174.

${ }^{1}$ Plank, Plank, Encyclopedia of Accountting System, 5.

${ }^{2}$ Mahrous, Taxation in Ancient Egypt, p. C- D.

${ }^{3}$ Von Beckerath, "Smsy Hrw in der agyptischen vor-und fruzeit", MDIAK 14 (1956): 6.

${ }^{4}$ Heinrich Schaffer, Ein Bruchstuck Altagyptischer Annalen (Berlin: akademie der wissenschaften, 1902).

${ }^{5}$ H- Goedicke, "Koniglische Dokumente aus dem Alten Reich" , JEA 42 (1956): 50-53.

${ }^{6}$ Von Bissing, Kees, Das Ra- Heilegtum des Konig Ne- Wsr- Ra, vol. II (Leipzig: Hinrichs, 1905-1928), 1. 3 .

${ }^{7}$ Mahrous, Taxation in Ancient Egypt, 20, 38- 39, 320- 321.

${ }^{8}$ Hermann Junker, "Gîza 5. Die Mastaba des Snb (Seneb) und die umliegenden Gräber. Akademie der Wissenschaften", Wien Philosophisch-historische Klasse Denkschriften 71 (Leipzig: Hölder- PichlerTempsky 1941), 76 . 
The concept of Account-Lists in Ancient Egypt

\begin{tabular}{|c|c|c|c|c|}
\hline & $\begin{array}{l}\text { D- Chesterbity } \\
\text { Papyrus }{ }^{1}\end{array}$ & & & \\
\hline $\begin{array}{l}(h t r) \\
\& \propto f \Longleftarrow\end{array}$ & $\begin{array}{l}\text { A- Chesterbity } \\
\text { Papyrus } \mathrm{V}^{2} \\
\mathrm{~B} \text { - The house } \\
\text { of the governor } \\
\text { of the reign of } \\
\text { Rameses } \mathrm{II}^{3}\end{array}$ & $\begin{array}{l}\text { Urk,IV,1236 } \\
, 16 \\
\text { KRI,II, } \\
197,10\end{array}$ & Amount Tax & $\begin{array}{l}\text { Means } \\
\text { the amount of } \\
\text { the tax in } \\
\text { particular, } \\
\text { regardless of } \\
\text { the quality of } \\
\text { the tax }\end{array}$ \\
\hline $\begin{array}{l}(s m w, b 3 k w) \\
\sum_{1}\end{array}$ & $\begin{array}{l}\text { A- Wilpour } \\
\text { Ppyrus }^{4} \\
\text { B- Louvre } \\
\text { Papyrus E } \\
3226^{5} \\
\text { C- Griffith } \\
\text { Papyrus } \\
{ }^{6} \\
\text { D- Valancy } \\
\text { Papyrus } \\
\text { E- Turin } \\
\text { Papyrus } \\
\end{array}$ & $\begin{array}{l}\text { Faulkner, CD, } \\
267 \\
\text { URK, IV, } \\
499,4\end{array}$ & Grain Tax & $\begin{array}{l}\text { The tax is } \\
\text { estimated } \\
\text { according to } \\
\text { the extent of } \\
\text { land use from } \\
\text { the flood water } \\
\text { and the impact } \\
\text { on the } \\
\text { productivity of } \\
\text { the land }\end{array}$ \\
\hline
\end{tabular}

${ }^{1}$ Davies, The Rock Tombs of Dier El Gabarawi (London: Cambridge library collection, 1900), Pl.vii.

${ }^{2}$ Hans Kayser, Die Mastaba des Uhemka, Ein Grab in der Wuste Hannover (Berlin: Fackeltrager-Verlag Verlag Schmidt-Kunster GmbH, 1964), 36- 37.

${ }^{3}$ Alan Gardiner, Hieratic Papyri in The British Museum $3^{\text {rd }}$ Series, Chester Beaty Gift ,Vol. 1 (London: British Museum, 1935), pl. xviii , R, 2-3, 37.

${ }^{4}$ David Lorton, The Juridical Terminology of international relations in Egyptian texts through Dyn. XVIII XVIII (London: Johns Hopkins University, 1974), 9.

${ }^{5}$ Alan Gardiner, Hieratic Papyri in The British Museum $2^{\text {nd }}$ Series ', Chester Beaty Gift ( London ,1935 ), 49.

${ }^{6}$ Meeks, Annee Lexicographique (Paris: Impr. de la Margeride, 1980), 793307, grg kmt .

${ }^{7}$ Mahrous, Taxation in Ancient Egypt, 323.

${ }^{8}$ Alan Gardiner, Papyrus Wilbour, 4 Vol (London: Oxford University Press, 1941). 
The concept of Account-Lists in Ancient Egypt

\begin{tabular}{|c|c|c|c|c|}
\hline & $\begin{array}{l}\text { Papyrus } \\
\text { No.1044 }\end{array}$ & & & \\
\hline 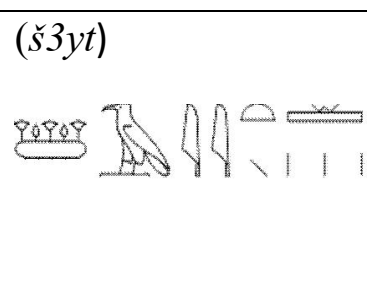 & $\begin{array}{l}\text { A-Neferty } \\
\text { prophecy }^{2} \\
\text { B-Renni Tomb } \\
\text { Tomb }\end{array}$ & $\begin{array}{l}\text { Wb,IV,402,8 } \\
\text { Wb,IV,403, 9- } \\
10\end{array}$ & $\begin{array}{l}\text { Occupational } \\
\text { tax }\end{array}$ & $\begin{array}{l}\text { Is the } \\
\text { estimated or } \\
\text { in-kind taxes }\end{array}$ \\
\hline $\begin{array}{l}(b 3 k w) \\
\sum_{1}^{*}=1\end{array}$ & $\begin{array}{l}\text { A-Leiden } \\
\text { Papyrus } \\
\text { No. } 344^{4} \\
\text { B-Turin } \\
\text { Papyrus } \\
\text { No. } 1874^{5} \\
\text { C- Ghwty- } m s \\
\text { Letter }^{6}\end{array}$ & $\begin{array}{l}\text { Wb, I, } 427 \\
\text { Faulkner, CD } \\
, 156\end{array}$ & $\begin{array}{l}\text { Production } \\
\text { Tax }\end{array}$ & $\begin{array}{l}\text { Pharaoh } \\
\text { Hormoheb } \\
\text { abolished so it } \\
\text { was not found } \\
\text { in the tax lists } \\
\text { recorded in the } \\
\text { Harris Papyrus }\end{array}$ \\
\hline 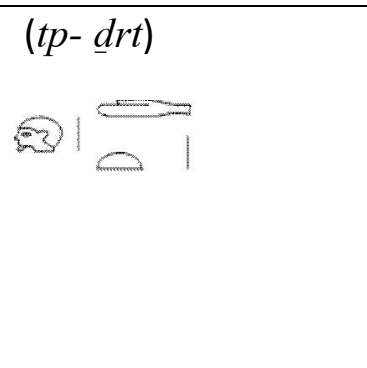 & $\begin{array}{l}\text { A-Turin } \\
\text { Papyrus } \\
\text { No. } 1874^{7} \\
\text { B-The text of } \\
\text { the priest } \\
\text { Amenhotep }\end{array}$ & $\begin{array}{l}\text { Meeks., } \\
\text { Lexicograph, } \\
793396\end{array}$ & Head tax & $\begin{array}{l}\text { Especially } \\
\text { Pharaoh only }\end{array}$ \\
\hline $\begin{array}{l}m h 3 w t \\
M B g A 口 M \square\end{array}$ & $\begin{array}{l}\text { A- Barcha } \\
\text { Text }^{9} \\
\text { B- Siti- } \\
\text { Decision- }\end{array}$ & $\begin{array}{l}\text { ASAE, 42, } \\
\text { P.108 }\end{array}$ & $\begin{array}{l}\text { Customs duties } \\
\text { tax }\end{array}$ & $\begin{array}{l}\text { This tax is } \\
\text { collected in } \\
\text { the form of } \\
\text { funds only, but } \\
\text { their value }\end{array}$ \\
\hline
\end{tabular}

\footnotetext{
${ }^{1}$ Megally, Notion de Comptabilites, 42.

${ }^{2}$ Mahrous, Taxation in Ancient Egypt, 152,176, 325.

${ }^{3}$ William Helck, Die Prophezeing Des Nfrti (Weisbaden: Otto Harrassowitz, 1970), 19.

${ }^{4}$ Jon Taylor, Wall Painting and Monuments of EL-Kab IV ,The Tomb of Renni (London: Quaritch, 1900 ) ), Pl. iii , iv.

${ }^{5}$ Mahrous, "Taxation in Ancient Egypt", 170, 326.

${ }^{6}$ Alan Gardiner, Admonitions of an Egyptian Sage, from a hieratic papyrus in Leiden Pap. Leiden 344 recto (Leipzig: Hinrichs, 1909), P. 72. Rt 10, 3- 10, 6.

${ }^{7}$ KRI, II, 819.

${ }^{8}$ Schafik Allam, Hieratische Ostraka und Papyri aus der Ramessiden Zeit (Tubingen: Postfach, 1973), PL.86, 278.

${ }^{9}$ Davies, The tomb of RKH- MI-RA, 52.
} 


\begin{tabular}{|l|l|l|l|}
\hline & Elfantini $^{1}$ & $\begin{array}{l}\text { varies either } \\
\text { by a third or a } \\
\text { half or by a } \\
\text { quarter } \\
\text { They are often } \\
\text { derived from } \\
\text { the word } m h 3 t \\
\text { in terms of the } \\
\text { scale }\end{array}$ \\
\hline
\end{tabular}

With regard to the competent authority to pay taxes and found as follows ${ }^{2}$ :

\begin{tabular}{|c|c|c|c|c|}
\hline Category & Text & Source & Mean & Remarks \\
\hline$(t 3-5 t)$ & $\begin{array}{l}\text { A-The text } \\
\text { of the priest } \\
\text { Amenhotep } \\
\text { B- } \\
\text { Chesterbity } \\
\text { PapyrusV }\end{array}$ & $\begin{array}{l}\text { Alan Gardiner, } \\
\text { Ramesside } \\
\text { Texts Relating } \\
\text { to the Taxation } \\
\text { and Transport } \\
\text { of Corn, JEA } \\
\text { 27, (1941) 67. }\end{array}$ & $\begin{array}{l}\text { Public } \\
\text { taxpayers }\end{array}$ & $\begin{array}{l}\text { Sometimes translated } \\
\text { as tax collectors }\end{array}$ \\
\hline $\begin{array}{l}(\text { nmhyw) } \\
\text { mans } 800 \text { s? }\end{array}$ & $\begin{array}{l}\text { A- } \\
\text { Pharaoh's } \\
\text { decree Hur- } \\
\text { Moheb } \\
\text { B- Dakhla } \\
\text { Stela }^{4}\end{array}$ & $\begin{array}{l}\mathrm{Wb}, \mathrm{II}, 268,4 \text {, } \\
5 .\end{array}$ & $\begin{array}{l}\text { Private } \\
\text { taxpayers }\end{array}$ & $\begin{array}{l}\text { They are the servants } \\
\text { of pharaoh's treasury }\end{array}$ \\
\hline$(s m d t)$ & $\begin{array}{l}\text { A- First } \\
\text { intermediate } \\
\text { Stela }^{5} \\
\text { B-A Text } \\
\text { for a }\end{array}$ & $\begin{array}{l}\text { Faulkner, CD, } \\
229 . \\
\text { URK,IV, 94, } 4\end{array}$ & $\begin{array}{l}\text { Young } \\
\text { users }\end{array}$ & $\begin{array}{l}\text { They occupy small } \\
\text { occupations }\end{array}$ \\
\hline
\end{tabular}

${ }^{1}$ Alan Gardiner, the Royal Canon of Turin, Griffith Institute (Oxford: Griffith Institute at the University, 1959), Pls. V- IX.

${ }^{2}$ Mahrous, "Taxation in Ancient Egypt", E -G.

${ }^{3}$ P. Chester Beatty, V, rt.7, 12- 8.

${ }^{4}$ Alan Gardiner., "The Dakhla Stela", JEA 19 (1933): 21.

5 Dows Dunham, Naga ed Der Stelae From First Intermediate Period (Boston: Museum of fine arts, 1937), PL. XIII A2, 43 N. 30. 
The concept of Account-Lists in Ancient Egypt

\begin{tabular}{|c|c|c|c|c|}
\hline & $\begin{array}{l}\text { cemetry } \\
\text { worker }^{1}\end{array}$ & & & \\
\hline $\begin{array}{l}\text { swotyw } \\
\text { PQ }\end{array}$ & $\begin{array}{l}\text { A- Harris } \\
\text { Papyris I }{ }^{2} \\
\text { B- Boulaq } \\
\text { Papyrus II } \\
\text { C- Lancing } \\
\text { Papyrus }^{3} \\
4,8-10\end{array}$ & $\begin{array}{l}\text { Wb, IV, 434, } \\
1-4 \\
\text { Meeks., } \\
\text { Lexicograph, } \\
792951 .\end{array}$ & Merchants & $\begin{array}{l}\text { They are divided into } \\
\text { three categories: } \\
\text { (A) a class working } \\
\text { for the temples. } \\
\text { (B) A category that } \\
\text { works for individuals. } \\
\text { (C) A class that } \\
\text { exercises self- } \\
\text { employment in favor } \\
\text { of its own profit. }\end{array}$ \\
\hline
\end{tabular}

\section{Categories:}

The main task of the clerks was the registration and statistics operations. Some clerks who carried out the census were called $h s b$. Each administration was distinguished by separate accounts, with a specific number of clerks and accountants. The accountants were found in the private administration under the supervision of the Chief of Accounts imy-r pr hsbw $\square{ }^{4}$ In addition to these special account clerks, some of the clerks held the title of accountant $s \grave{s} h s b$ 国政 In general $^{5}$, as the officials responsible responsible for recording the statistics are mainly accountants; this is done through their specialization as follows ${ }^{6}$ :

A-Cattle Scribes ${ }^{(7)}$ :

${ }^{1}$ Jarsolav Cerny, Community of Worken in Thebes in the Ramesside Period (Cairo: Bibliothèque d'études IFAO, 1937), $183 \mathrm{ff}$.

${ }^{2}$ P.Harris , I , 46, 2.

${ }^{3}$ Walter Reinike, "Waren die Swtyw wirklich kaufleute", AF 6 (1979): 10.

${ }^{4}$ Mohammed Ali, "Titles and civil functions in the era of the new kingdom" (unpublished MA thesis, Mansoura University Faculty of Arts, 2012), 311.

${ }^{5}$ Ali, "Titles and civil functions in the era of the new kingdom", 311.

${ }^{6}$ Geoffery Martin, The tomb of Hetepka and Other Reliefs and Inscriptions from the Sacred Animal Necropolis, North Saqqara (London: Egypt Exploration Society, 1964-73), 10, Pl. ii, 9.

${ }^{7}$ Ali, "Titles and civil functions in the era of the new kingdom", 315-321. 
The concept of Account-Lists in Ancient Egypt

\begin{tabular}{|c|c|c|c|c|}
\hline Title & Texts & Source & Mean & Remarks \\
\hline $\begin{array}{l}h s b i h w \\
\frac{x-\pi}{x}\end{array}$ & $\begin{array}{l}\text { A-An } \\
\text { inscription of } \\
\text { conical for the } \\
\text { priest Nefer } \\
\text { Renbet }\end{array}$ & $\begin{array}{l}\text { Norman } \\
\text { Davies, } \\
\text { Miles } \\
\text { Macadam., } \\
\text { A Corpus of } \\
\text { Inscribed } \\
\text { Egyptian } \\
\text { Funerary } \\
\text { Cones I, } \\
\text { (Oxford: } \\
\text { Oxford } \\
\text { University } \\
\text { Press, 1957) } \\
\text { 464. }\end{array}$ & Cattle scribe & $\begin{array}{l}\text { Tomb } \\
\text { No.43 } \\
\text { El- hwza } \\
\text { el-olya }\end{array}$ \\
\hline 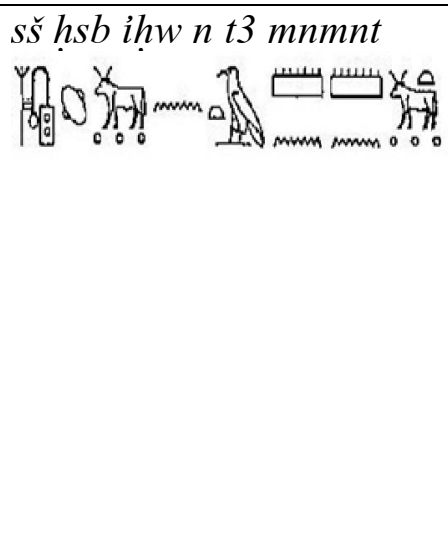 & $\begin{array}{l}\text { Inscription of } \\
\text { byai tomb }\end{array}$ & $\begin{array}{l}\text { Lefebvre., } \\
\text { Histoire des } \\
\text { grand pretres } \\
d^{\prime} \text { Amon de } \\
\text { Karnak, } \\
\text { (Paris: } \\
\text { Cambridge } \\
\text { University } \\
\text { Press, 1929) } \\
131 .\end{array}$ & $\begin{array}{l}\text { scribe and } \\
\text { accountant of } \\
\text { herd bulls }\end{array}$ & $\begin{array}{l}\text { Tomb } \\
\text { No.263 } \\
\text { Sheikh } \\
\text { abd el } \\
\text { korna }\end{array}$ \\
\hline 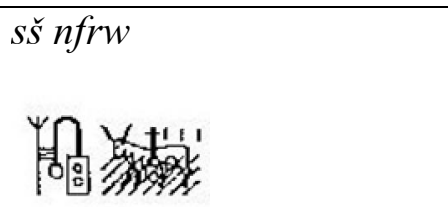 & $\begin{array}{l}\text { Inscription of } \\
\text { amon- em-ubet } \\
\text { tomb }\end{array}$ & $\begin{array}{l}\text { KRI, I, } 385 \\
\text { (6) }\end{array}$ & Cows scribe & $\begin{array}{l}\text { Tomb } \\
\text { No.265 } \\
\text { Deir el- } \\
\text { madina }\end{array}$ \\
\hline 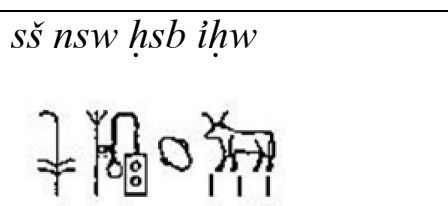 & $\begin{array}{l}\text { Inscription of } \\
\text { Sa- mut tomb }\end{array}$ & $\begin{array}{l}\text { KRI, III, } 334 \\
(10)\end{array}$ & $\begin{array}{l}\text { Royal scribe } \\
\text { accountant of } \\
\text { bulls }\end{array}$ & $\begin{array}{l}\text { Tomb } \\
\text { No.409 } \\
\text { Assassif }\end{array}$ \\
\hline
\end{tabular}


The concept of Account-Lists in Ancient Egypt

\begin{tabular}{|c|c|c|c|c|}
\hline imy-rhsbihw & $\begin{array}{l}\text { Inscription of } \\
\text { Sa- mut tomb }\end{array}$ & $\begin{array}{l}\text { Abdel kader } \\
\text { Muhammed., } \\
\text { " The Hittite } \\
\text { Provincial } \\
\text { Administratio } \\
\text { n of } \\
\text { Conquered } \\
\text { Territories", } \\
\text { ASAE, 59, } \\
\text { (1966), PL. } \\
\text { XXXIV }\end{array}$ & $\begin{array}{l}\text { The overseer } \\
\text { of bulls } \\
\text { accounts }\end{array}$ & ------ \\
\hline 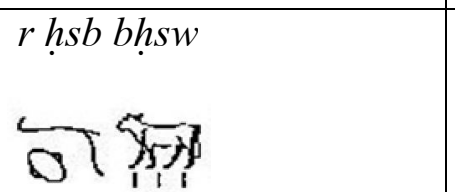 & $\begin{array}{l}\text { Inscription of } \\
\text { Sa-mut tomb }\end{array}$ & $\begin{array}{l}\text { KRI , III, } 334 \\
\text { (8) }\end{array}$ & $\begin{array}{l}\text { The overseer } \\
\text { of calves } \\
\text { accounts }\end{array}$ & $\begin{array}{c}----- \\
-\end{array}$ \\
\hline 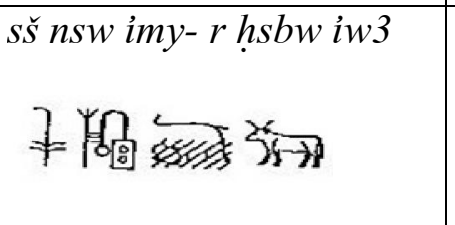 & $\begin{array}{l}\text { Inscription of } \\
\text { Sa- mut tomb }\end{array}$ & $\begin{array}{l}\text { Muhammed, } \\
\text { The Hittite } \\
\text { Provincial, } \\
\text { PL. LXXIII }\end{array}$ & $\begin{array}{l}\text { The royal } \\
\text { scribe, } \\
\text { overseer of } \\
\text { oxen account }\end{array}$ & ------ \\
\hline $\begin{array}{l}\text { šs } n s w \text { imy }-r \text { hbsw ihw } n \\
\text { šm } w \text { mhw }\end{array}$ & $\begin{array}{l}\text { An inscription } \\
\text { of conical for } \\
\text { the priest } \\
\text { amon- ms }\end{array}$ & $\begin{array}{l}\text { KRI , III, } 334 \\
\text { (4) } \\
\text { Muhammed, } \\
\text { The Hittite } \\
\text { Provincial, } \\
\text { Pl.xxxvi. }\end{array}$ & $\begin{array}{l}\text { The royal } \\
\text { scribe, } \\
\text { overseer of } \\
\text { calves } \\
\text { accounts of } \\
\text { North and } \\
\text { South gods }\end{array}$ & $\begin{array}{l}\text { Tomb } \\
\text { No.9 } \\
\text { Deir el- } \\
\text { madina }\end{array}$ \\
\hline
\end{tabular}

In ancient Egypt, the census of cattle was carried out periodically - usually every two years. This process was sometimes linked to the imposition of a specific tax for the government ${ }^{1}$. It was conducted under the supervision of the head of the herd or the royal archivist and representatives of the government. Farms in the provinces ${ }^{2}$, there is no doubt that the herd was included on all types of cattle of cows and bulls of different types besides small calves, and the process of counting livestock depends on the classification of these species and discrimination.

\footnotetext{
${ }^{1}$ Norman Davies, The Tomb of Kenamun, (New york: Metropolitan Museum of art, 1865-1941), Pls. xxvi- xxvii.

Urk iv: 1394 (3- 4)

${ }^{2}$ Ali, "Titles and civil functions in the era of the new kingdom", 312.
} 
B-Birds scribes ${ }^{1}$ :

\begin{tabular}{|c|c|c|c|c|}
\hline Title & Texts & Source & Mean & Remarks \\
\hline 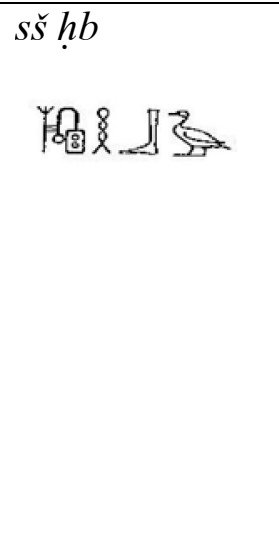 & $\begin{array}{l}\text { Inscription } \\
\text { of Ghwty- } \\
\text { nfr tomb }\end{array}$ & $\begin{array}{l}\text { Georges } \\
\text { Daressy, } \\
\text { "Receuil de } \\
\text { Cones } \\
\text { Funeraires", } \\
\text { Mission } \\
\text { archéologique } \\
\text { française au } \\
\text { Caire, } 8 \text { (1893), } \\
\text { n.165 }\end{array}$ & Birds scribe & $\begin{array}{l}\text { Tomb No. } 317 \\
\text { Sheikh abd el } \\
\text { korna }\end{array}$ \\
\hline 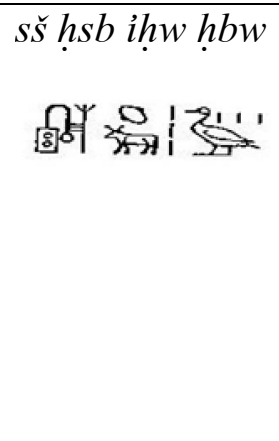 & $\begin{array}{l}\text { Inscription } \\
\text { of Ghwty- } \\
\text { nfr tomb }\end{array}$ & $\begin{array}{l}\text { Herny Gauthier, } \\
\text { "Rapport sur } \\
\text { une campagne } \\
\text { de fouilles à } \\
\text { Drah abou'l } \\
\text { Neggah" } \\
\text { BIFAO, } 6 \\
(1908), 124\end{array}$ & $\begin{array}{l}\text { The scribe } \\
\text { and } \\
\text { accountant of } \\
\text { bulls and } \\
\text { birds }\end{array}$ & ------- \\
\hline
\end{tabular}

The Karnak temple included the sheds for the raising of birds, poultry and geese to provide the sacred offerings of the temple's deities, and there was carried the post of writer and accountant of cattle and birds of Amun as mentioned above.

C-Treasury scribes ${ }^{2}$ :

\begin{tabular}{|c|c|c|c|c|}
\hline Title & Texts & Source & Mean & Remarks \\
\hline 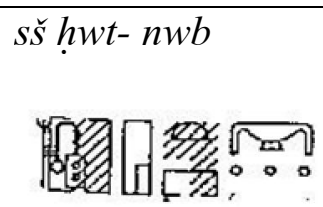 & $\begin{array}{l}\text { An inscription } \\
\text { of conical for } \\
\text { the priest } \\
\text { Nefer Renbet }\end{array}$ & $\begin{array}{l}\text { KRI, III, } 330 \\
\text { (1) }\end{array}$ & $\begin{array}{l}\text { The } \\
\text { scribe of } \\
\text { gold } \\
\text { residence }\end{array}$ & ------- \\
\hline
\end{tabular}

${ }^{1}$ Ali, "Titles and civil functions in the era of the new kingdom", 322.

2 Ali, "Titles and civil functions in the era of the new kingdom", 323. 
The concept of Account-Lists in Ancient Egypt

\begin{tabular}{|c|c|c|c|c|}
\hline $\begin{array}{l}s \check{s} p r-h \underline{d} \\
\text { \% }\end{array}$ & $\begin{array}{l}\text { A- Inscription } \\
\text { of User-hat } \\
\text { tomb }\end{array}$ & $\begin{array}{l}\text { Ahmed } \\
\text { Fakhry, " A } \\
\text { Report on } \\
\text { the } \\
\text { Inspectorate } \\
\text { of Upper } \\
\text { Egypt", } \\
\text { ASAE , 46, } \\
(1947), 44 \\
\text { PM I : I, } \\
427-428\end{array}$ & $\begin{array}{l}\text { The scribe } \\
\text { of treasury }\end{array}$ & $\begin{array}{l}\text { Tomb No.56 } \\
\text { Sheikh abd el } \\
\text { korna }\end{array}$ \\
\hline 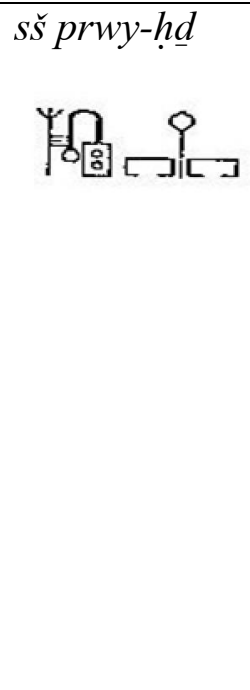 & $\begin{array}{l}\text { A- inscription } \\
\text { of conical for } \\
\text { the priest } \\
\text { Nefer Renbet } \\
\text { B-The } \\
\text { Memorial } \\
\text { inscription } \\
\text { No.1960 } \\
\text { western } \\
\text { Thebes }\end{array}$ & $\begin{array}{l}\text { KRI, III, } 323 \\
\text { (4) }\end{array}$ & $\begin{array}{l}\text { The scribe } \\
\text { of dual } \\
\text { treasury }\end{array}$ & $\begin{array}{l}\text { A-This title, } \\
\text { called Amon - } \\
\text { Nekho Word, } \\
\text { was Memorial } \\
\text { inscription was } \\
\text { given to the } \\
\text { chief of the } \\
\text { workers at } \\
\text { Deir- Elmadina } \\
\text { Medina } \\
\text { B- inscription } \\
\text { of Hay tomb } \\
\text { NO.328 }\end{array}$ \\
\hline
\end{tabular}

The work of the workers inside the treasury was largely based on the category of clerks, where they concentrated on a lot of operations such as recording the quantities of raw materials used in artisans' workshops, recording the works that are finished by the manufacture. There is no lack of photocopying of the treasury or workshops of artisans there are a number of clerks holding their records the clerk of the treasury has some administrative tasks besides the calculations performed by the clerk of the treasury and many titles that show his assumption of the tasks of writing and accounts in the treasury ${ }^{1}$.

D-Sacred Seals Scribes:

\begin{tabular}{|l|l|l|l|l|}
\hline Title & Texts & Source & Mean & Remarks \\
\hline $\begin{array}{l}\text { š́ htmt- ntr tpy } \\
\text { on }\end{array}$ & $\begin{array}{l}\text { Inscription } \\
\text { tomb of } \\
\text { po- m- ra }\end{array}$ & $\begin{array}{l}\text { KRI, III, 225 } \\
(10)\end{array}$ & $\begin{array}{l}\text { The first scribe } \\
\text { for divine } \\
\text { treasury }\end{array}$ & $\begin{array}{l}\text { Tomb No.39 } \\
\text { Elkhokha }\end{array}$ \\
\hline
\end{tabular}

\footnotetext{
${ }^{1}$ Ali," Titles and civil functions in the era of the new kingdom", 323- 327.
} 
The concept of Account-Lists in Ancient Egypt

\begin{tabular}{|c|c|c|c|c|}
\hline 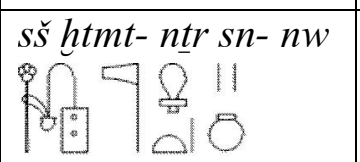 & $\begin{array}{l}\text { Inscription } \\
\text { tomb of } \\
\text { po- m- ra }\end{array}$ & $\begin{array}{l}\text { PM , I, } 393 \\
\text { (4) }\end{array}$ & $\begin{array}{l}\text { The second } \\
\text { scribe for } \\
\text { divine treasury }\end{array}$ & ----- \\
\hline 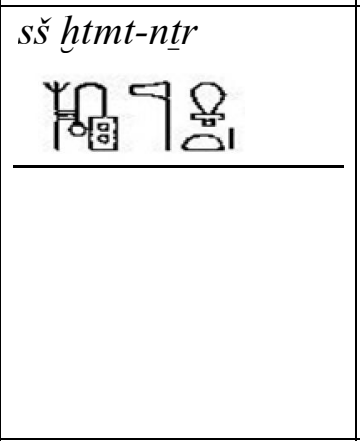 & $\begin{array}{l}\text { A- } \\
\text { Inscription } \\
\text { tomb of } \\
\mathrm{Nb}-\mathrm{Kdnw} \\
\mathrm{B}- \\
\text { Inscription } \\
\text { tomb of } \\
\text { Sr-Ws }\end{array}$ & $\begin{array}{l}\text { KRI, III, 358, } \\
\text { (6) }\end{array}$ & $\begin{array}{l}\text { The scribe of } \\
\text { divine treasury }\end{array}$ & $\begin{array}{l}\text { B-Tomb No. } \\
232 \text { Draa Abu el } \\
\text { naga }\end{array}$ \\
\hline htm htmwt nbt & $\begin{array}{l}\text { Inscription } \\
\text { tomb of } \\
\text { aniny }\end{array}$ & $\begin{array}{l}\text { Urk, iv, } 68 \\
\text { (11) }\end{array}$ & $\begin{array}{l}\text { The bigger of } \\
\text { all seals }\end{array}$ & $\begin{array}{l}\text { Tomb No.31 El- } \\
\text { Hoza el ulya }\end{array}$ \\
\hline imy-r htmt nbt & $\begin{array}{l}\text { Inscription } \\
\text { tomb of } \\
\text { aniny }\end{array}$ & $\begin{array}{l}\text { Urk, iv, 68, } \\
(15-17)\end{array}$ & $\begin{array}{l}\text { The overseer } \\
\text { of all seals }\end{array}$ & ----- \\
\hline 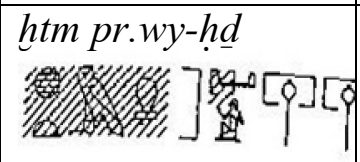 & $\begin{array}{l}\text { Inscription } \\
\text { tomb of } \\
\text { Ghwty }\end{array}$ & $\begin{array}{l}\text { Urk, iv, } 429 \\
(6), 436 \\
(15-17)\end{array}$ & $\begin{array}{l}\text { The teasurer of } \\
\text { dual treasury }\end{array}$ & $\begin{array}{l}\text { Tomb No. } 11 \\
\text { Draa Abu el } \\
\text { naga }\end{array}$ \\
\hline
\end{tabular}

The title of the divine seal "sš htmt-ntr" appeared in the old kingdom, and the title of the author of all the divine seals $s \check{s}$ htmt-ntr $n b t$ was one of the titles carried by the priests and treasury workers in the new kingdom and the era of the Ramses. The task of seals writers was to register the foreign products of the country whether imported into the treasury such as precious metals, textiles and textiles; or other products such as cattle, monkeys, and leather and bird feathers ${ }^{1}$.

E-The Barn Scribes:

\begin{tabular}{|l|l|l|l|l|}
\hline Title & \multicolumn{1}{|c|}{ Texts } & Source & \multicolumn{1}{|c|}{ Mean } & Remarks \\
\hline šs šnwt & $\begin{array}{l}\text { Inscription } \\
\text { tomb of } \\
\text { Menna }\end{array}$ & $\begin{array}{l}\text { Margret Murray, } \\
\text { Index of Names } \\
\text { and Titles of the } \\
\text { old kingdom, } \\
\text { (London: Office } \\
\text { of British } \\
\text { School of }\end{array}$ & $\begin{array}{l}\text { The barn } \\
\text { scribe }\end{array}$ & Tomb No. 69 \\
& & & \\
& & & \\
\hline
\end{tabular}

${ }^{1}$ Ali, "Titles and civil functions in the era of the new kingdom", 330. 


\begin{tabular}{|c|c|c|c|c|}
\hline & & $\begin{array}{l}\text { Archaeology190 } \\
\text { 8), pl. xliii ; } \\
\text { Wolfgang } \\
\text { Helck, } \\
\text { Undersuchunge } \\
\text { n zu den } \\
\text { Beamentiteln } \\
\text { des Alten } \\
\text { Reiches, } \\
\text { (Hamburg: } \\
\text { Verlag Augustin } \\
\text { 1975), plate } \\
\text { xxxviiix }\end{array}$ & & \\
\hline 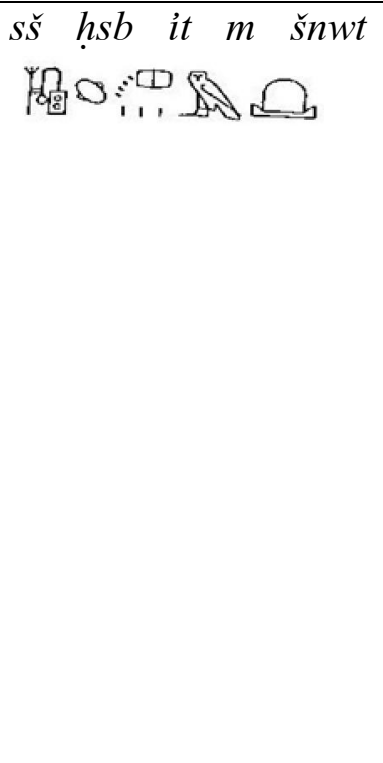 & $\begin{array}{l}\text { A- } \\
\text { Inscription } \\
\text { tomb of } \\
\text { Sennefr } \\
\text { B- } \\
\text { Inscription } \\
\text { tomb of } \\
\text { Neb- } \\
\text { Amun }\end{array}$ & $\begin{array}{l}\text { Murray, Index of } \\
\text { Names, } 64 \\
\text { Urk, iv, } 1049 \\
(15), 1051 \text { (7) }\end{array}$ & $\begin{array}{l}\text { The } \\
\text { scribe of } \\
\text { barn } \\
\text { accounts }\end{array}$ & 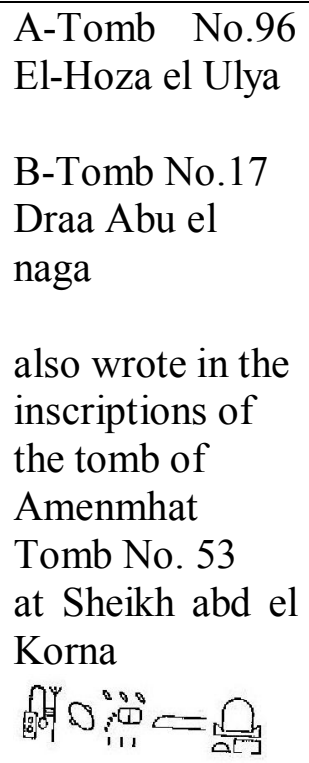 \\
\hline
\end{tabular}

The barn scribes ${ }^{1}$ were assigned to the registration and calculation of yields and quotas. They can be categorized into three categories, beginning with clerks, supervised by the censor of the library clerks and headed by the supervisor of the library clerks. The clerks specialize in the fields in several fields. (Records) and supervised by the head of the archives of the archives of the Barn and have existed these specialties between the clerks of the Barn since the old and the middle and found the titles as mentioned above ${ }^{2}$.

\footnotetext{
${ }^{1}$ For more details on this point, see:

Khaled Awad, Grain Stores in Ancient Egypt, Ain for Human and Social Studies and Research (Cairo: Ain for human and social studies and research, 2007).

${ }^{2}$ Ali, "Titles and civil functions in the era of the new kingdom", 334.
} 
The concept of Account-Lists in Ancient Egypt

F-Stores Scribe:

\begin{tabular}{|c|c|c|c|c|}
\hline Title & Texts & Source & Mean & Remarks \\
\hline $\begin{array}{l}\text { š́ hsb itw m šnwt } \\
h t p-n t r\end{array}$ & $\begin{array}{l}\text { A- } \\
\text { Inscription } \\
\text { tomb of } \\
\text { Neb-Amun } \\
\text { B- } \\
\text { Inscription } \\
\text { tomb of } \\
\text { Ghwty- nfr }\end{array}$ & $\begin{array}{l}\text { Urk, iv, } 1050 \\
(13,15), 1050 \\
(3), 1052(15- \\
16)\end{array}$ & $\begin{array}{l}\text { The } \\
\text { accountant } \\
\text { scribe of } \\
\text { crops in barn } \\
\text { of offerings }\end{array}$ & ------ \\
\hline 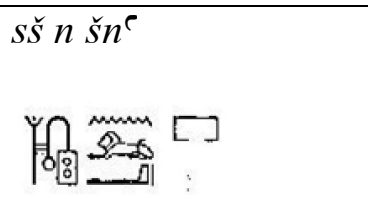 & $\begin{array}{l}\text { Inscription } \\
\text { tomb of } \\
\text { biay }\end{array}$ & $\begin{array}{l}\text { KRI, III, 381(4- } \\
5),(7-8)\end{array}$ & Stores scribe & ------ \\
\hline $\begin{array}{l}s \check{s} w d h w \\
\text { \% }\end{array}$ & $\begin{array}{l}\text { Inscription } \\
\text { tomb of } \\
\text { Amwn- Htp }\end{array}$ & $\begin{array}{l}\text { Daressy, Receuil } \\
\text { de Cones, Nos } \\
\text { 264- } 266\end{array}$ & $\begin{array}{l}\text { The offerings } \\
\text { scribe }\end{array}$ & $\begin{array}{l}\text { A-Tomb No.73 El- } \\
\text { Hoza el Ulya }\end{array}$ \\
\hline 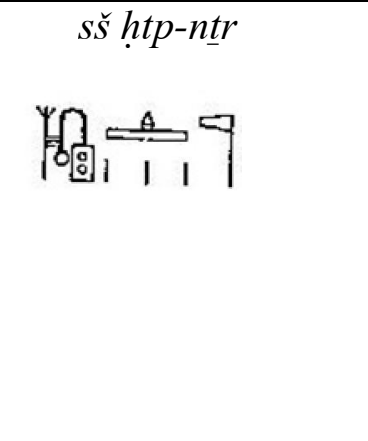 & $\begin{array}{l}\text { Inscription } \\
\text { tomb of } \\
3 m w n-h t p\end{array}$ & $\begin{array}{l}\text { Norman Davies, } \\
\text { "Some } \\
\text { Representations } \\
\text { of Tombs from } \\
\text { the Theban } \\
\text { Necropolisin" } \\
J E A, 24 \text {, } \\
(1938), \text { fig .8 }\end{array}$ & $\begin{array}{l}\text { The scribe of } \\
\text { divine } \\
\text { offerings }\end{array}$ & ------ \\
\hline 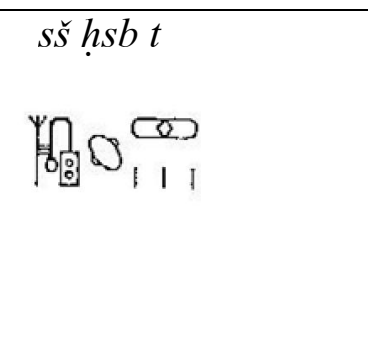 & $\begin{array}{l}\text { Inscription } \\
\text { tomb of } \\
\text { Amwn-Htp } \\
\text { Inscription } \\
\text { tomb of } \mathrm{Nb} \text { - } \\
\text { Amwn }\end{array}$ & $\begin{array}{l}\text { Daressy, Receuil } \\
\text { de Cones, n.47 }\end{array}$ & $\begin{array}{l}\text { The scribe } \\
\text { and } \\
\text { accountant of } \\
\text { bread }\end{array}$ & ------ \\
\hline 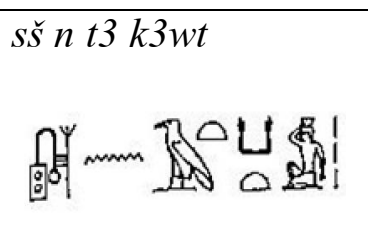 & $\begin{array}{l}\text { Inscription } \\
\text { tomb of } \\
\text { Inhr- ms }\end{array}$ & $\begin{array}{l}\text { Davies, } \\
\text { Macadam, } A \\
\text { Corpus of } \\
\text { Inscribed, n. } 430\end{array}$ & Works scribe & ----- \\
\hline
\end{tabular}


The concept of Account-Lists in Ancient Egypt

\begin{tabular}{|c|c|c|c|c|}
\hline $\begin{array}{l}s s ̌ h m w t n b t \\
\text { 用㢣口 } 0 \sqcup\end{array}$ & $\begin{array}{l}\text { Inscription } \\
\text { tomb of } \\
\text { Amwn- Htp }\end{array}$ & $\begin{array}{l}\text { Davies, } \\
\text { Macadam, } \\
\text { A Corpus of } \\
\text { Inscribed, n. } \\
354\end{array}$ & $\begin{array}{l}\text { The scribe of } \\
\text { all crafts }\end{array}$ & ----- \\
\hline
\end{tabular}

In addition to this, a group of other employees, similar to their clerks, was found to be the surveyors who measured the area of grain fields before harvesting to estimate the quantity of the crop that would enter Shun As titles mentioned above ${ }^{1}$.

G- Secondary Administrative Departments Scribes:

\begin{tabular}{|c|c|c|c|c|}
\hline Title & Texts & Source & Mean & Remarks \\
\hline $\begin{array}{l}s \check{s} p r m \underline{d} 3 t \\
\square \\
\square\end{array}$ & $\begin{array}{l}\text { Inscription } \\
\text { of a } \\
\text { worker of } \\
\text { Deir- } \\
\text { Elmadina }\end{array}$ & $\begin{array}{l}\text { Murray, Index of } \\
\text { Names, PL. xxxviii }\end{array}$ & $\begin{array}{l}\text { The scribe } \\
\text { of books } \\
\text { house }\end{array}$ & -------- \\
\hline $\begin{array}{l}s \check{s} s t d f 3 w t \\
\text { कृ } \leftrightharpoons=\end{array}$ & $\begin{array}{l}\text { Inscription } \\
\text { of a worker } \\
\text { of Deir- } \\
\text { Elmadina }\end{array}$ & $\begin{array}{l}\text { Murray, Index of } \\
\text { Names, PL. xxxvii }\end{array}$ & $\begin{array}{l}\text { The scibe } \\
\text { of food } \\
\text { section }\end{array}$ & $\begin{array}{l}\text { It emerged } \\
\text { from the era } \\
\text { of the } \\
\text { Second } \\
\text { Dynasty }\end{array}$ \\
\hline 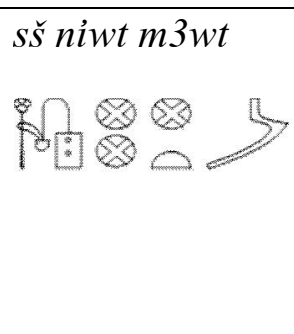 & $\begin{array}{l}\text { Inscription } \\
\text { of a worker } \\
\text { of Deir- } \\
\text { Elmadina }\end{array}$ & $\begin{array}{l}\text { Abdel Moneim } \\
\text { Abubakr, } \\
\text { Excavations at } \\
\text { Giza,I (Cairo: } \\
\text { Government Press, } \\
\text { 1953), 69, } 75 .\end{array}$ & $\begin{array}{l}\text { The scribe } \\
\text { of new } \\
\text { cities }\end{array}$ & ------ \\
\hline $\begin{array}{l}\text { ss hwt } \\
\text { ping } 80\end{array}$ & $\begin{array}{l}\text { Inscription } \\
\text { of a } \\
\text { worker of } \\
\text { Deir- } \\
\text { Elmadina }\end{array}$ & $\begin{array}{l}\text { Paul Smither, } \\
\text { "A Tax- Assessor's } \\
\text { Journal of the } \\
\text { Middle Kingdom" } \\
J E A, 27(1941), 74 .\end{array}$ & $\begin{array}{l}\text { Fields } \\
\text { scribe }\end{array}$ & $\begin{array}{l}\text { Sometimes } \\
\text { wrote } \\
s \check{s} 3 h w t\end{array}$ \\
\hline
\end{tabular}

${ }^{1}$ Ali, Titles and civil functions in the era of the new kingdom, 334- 339. 
The concept of Account-Lists in Ancient Egypt

\begin{tabular}{|c|c|c|c|c|}
\hline $\begin{array}{l}\text { ss tst } \\
\text { Das }\end{array}$ & $\begin{array}{l}\text { Inscription } \\
\text { of a } \\
\text { worker of } \\
\text { Deir- } \\
\text { Elmadina }\end{array}$ & $\begin{array}{l}\text { Selim Hassan, } \\
\text { Excavation at Giza, } \\
\text { II, (Cairo: } \\
\text { Government Press } \\
\text { 1936), } 96\end{array}$ & $\begin{array}{l}\text { Workers } \\
\text { scribe }\end{array}$ & --------- \\
\hline $\begin{array}{l}5 s g s \text { wi3 } \\
s_{0}=\end{array}$ & $\begin{array}{l}\text { Inscription } \\
\text { of a } \\
\text { worker of } \\
\text { Deir- } \\
\text { Elmadina }\end{array}$ & $\begin{array}{l}\text { Murray, Index of } \\
\text { Names, PL. xxxviii }\end{array}$ & $\begin{array}{l}\text { The ship } \\
\text { scribe }\end{array}$ & ----- \\
\hline
\end{tabular}

The old Egyptian could express the function of the clerk of the departments or administrative departments or the author of the specialization depending on the circumstances surrounding each department and we can distinguish the administration by the titles taken by the writer, and can be limited in two types through the composition of verbal; The first type is that the first $s \check{s}$ has a close relationship with the names of the departments that are defined by the word $p r{ }_{1}$, which means "house", the second type defined by the word st , the third type is defined by the names of regions, the fourth type is specific to specific jurisdictions, the fifth type is specific groups as mentioned above ${ }^{1}$.

\section{General Form:}

The Ancient Egyptian has known a fixed system for recording his daily and public accounts. This is evident in the various texts written on the papyri and dioceses mentioned above. It seems that this system was started since the early ages. It is clear from us that seals and seals of books and cards written from the era of the first two families with a specific recording system for accounts ${ }^{2}$.

The statistical text usually consists of certain elements:

(A) The registered or registered material

(B) The unit of the article, i.e. the unit to which this article is attached.

(C) The quantity assigned to that unit.

(D) Some data on the recorded statistical process.

The mathematical and statistical documents had their distinctive form from other documents. However, this form differed and developed according to the age of the papyrus or the arithmetic document ${ }^{3}$.

\footnotetext{
${ }^{1}$ Megally, "The Post of the Writer in the Age of the Old Kingdom" (unpublished MA thesis, University of Alexandria, Faculty of Arts, 1955), 26- 31.

2 Stephen Quirke, Administrative Texts, Redford Encyclopedia, 1(Oxford: Oxford University Press, 2001), 24

${ }^{3}$ Sherif, "A collection of administrative hierarchies", 16.
} 


\section{The concept of Account-Lists in Ancient Egypt}

Firstly: the old kingdom:

The most important characteristic of the arithmetic text in the old kingdom is the great detail in the recording of accounts and statistics. The scribes were keen to record their statistics within overlapping horizontal and vertical lines or in other words in square boxes resulting from horizontal and vertical lines.

The data for both of the various resources, units and quantities has been given to the arithmetic bar in the old kingdom a distinctive geometric shape in the presence of this tabular form ${ }^{1}$ (see Table 1). This complex geometric form, which distinguishes Abu sir papyrus as a model of the old kingdom calculations, Which is the size of the compass in the old kingdom in size between the size of the medium or new kingdom papyrus, where the height of $21-24 \mathrm{~cm}$, the red ink was used in public papyrus to indicate the quantities as well as the overall balance ${ }^{2}$, and wrote lines Writing horizontally and vertically while the vertical columns were predominant ${ }^{3}$.

Secondly: Middle kingdom:

In the Middle Kingdom, the detailed spirit of recording statistics and accounts was less than in the old kingdom, Some of the models that belong to that period- with the full shape of the table ${ }^{4}$ (horizontal and vertical lines)- are different from those in the old kingdom with relatively large volumes and thus the clarity of the words within the different cells ${ }^{5}$.

This is due to the large size of the statistical papyrus in the middle country than in any other era. Therefore, the pages came with a large quantity of accounts, as well as large margins on both sides ${ }^{6}$. The boxes or boxes disappeared little by little until there was no existence of these tables, there is also a horizontal line after each horizontal line of writing ${ }^{7}$, and there is a note on the accounts of the middle and old kingdom. It is concerned with writing the name of the unit used in the various articles. That among the statistical registers as follows:

(A) The name of the registered material.

(B) The name of the unit in which that article is directly attached.

(C) A custom form of the word indicating unity.

(D) Quantity use.

We note this also on some of the old kingdom paintings. The text of the article itself is written in a separate box, perhaps a reference to the unit assigned to that article ${ }^{8}$, and the red color was used in this period. It is used in the Raisner papyrus to denote the names of the absent workers.

Thirdly: New Kingdom:

The most characteristic of the new kingdom statistical records is the extreme simplification of all the different elements ${ }^{9}$. The most important observation of the

\footnotetext{
${ }^{1}$ M-Stevelick, "Accounting in Ancient Times": The Accounting historian Journals 12, No .1 (1985): 7-8.

2 Posener Krieger, De Cenival, Abu Sir Papyri, 211.

${ }^{3}$ Posener Krieger, De Cenival, Abu Sir Papyri, pls. xi, xii, xiii \& passim.

${ }^{4}$ Quirke, Administrative texts, 25.

${ }^{5}$ Magally, Notion de Comptabilites, 2.

${ }^{6}$ Simpson, Pap Reisner, passim.

7 Stevelick, "Accounting", 8.

${ }^{8}$ Quirke, Administrative texts, 25.

${ }^{9}$ Magally, Notion de Comptabilites, $4 \mathrm{ff}$.
} 


\section{The concept of Account-Lists in Ancient Egypt}

arithmetic corpus in this period, especially the 18 family is its small size as it is $18 \mathrm{~cm}$ high.

From the page and no longer leaves the large margins that we saw in the old and middle kingdom on both sides ${ }^{1}$, as the writer completely away from the tables and lines became horizontal writing is always prevailing and became the form of the arithmetic parody near the form of the literary papyrus ${ }^{2}$, meaning there is no vacuum Between the name of the article and quantity as it used to be; But the recording became consecutive as literary texts without spaces or detail in the line ${ }^{3}$.

The red color was used less than the old and middle kingdom, where it indicated the titles and some papyri ${ }^{4}$, and continued as was previously used in the texts containing the the quantities of wheat and barley $b d t$ - it where the barley was written the quantity of the function in black and write the quantity of the function The wheat was red, and the same use continued in the new kingdom ${ }^{5}$.

Fourthly: Demotic Accounts:

Demotic accounts are a type of text that takes the form of an account-lists list that records the amounts of money, grain, liquids, etc. These accounts start from the age of the 26th Dynasty and continued until the Greco-Roman era. We can confirm that it was used until the second century AD by discovering some papyrus ${ }^{6}$.

Zauzich $^{7}$ noted that the Demotic calculations were greatly extended in the Roman era. In comparison with the Ptolemaic calculations, Demotic calculations are the most written for everyday purposes Muhs ${ }^{8}$ sees that Demotic calculations have been extended extended to a Ptolemaic alike to the third century AD.

The overall average size of the demotic papyrus was $4.21 \mathrm{~cm}$ in length and $7.26 \mathrm{~cm}$ in width and the size of the ostarca was very varied with the form of the demotic account. The tabular form is no longer used in demotic calculations but we find it somewhat similar to the literary text as a result of the increase the need for Calculations the author took advantage of all the space in writing and the basic parts of writing the text of my arithmetic in demotic were as follows ${ }^{9}$ :

\section{\begin{tabular}{|l|l|l|}
\hline Closing Formula & Body of the Account & Heading Formula
\end{tabular}}

In the basic construction of the account the introduction of the so-called entries, which are fixed elements such as goods or component prepared, measuring any number referred to by the quantity, the person who received or sold...... $\mathrm{Etc}^{10}$.

\footnotetext{
${ }^{1}$ Magally, Notion de Comptabilites, 4- 5.

${ }^{2}$ Magally, Notion de Comptabilites, 5.

${ }^{3}$ Sherif, "A collection of administrative hierarchies", 19.

${ }^{4}$ Magally, Notion de Comptabilites, 11.

${ }^{5}$ Magally, Notion de Comptabilites, 6 Note. 4.

${ }^{6}$ Eid Nagy, "Demotic Accounts" (Un Published MA Thesis, Cairo University, Faculty of Archeology, 2016) 6 .

${ }^{7}$ Karl Zauzich, Die Demotischen Dokumente, Textes et Langages de L'Egypte Pharaonique cent Cinquente Annee de Recherches, Bde 64/3, (1972), 93.

${ }^{8}$ Brian Muhs, "Demotic and Greek Ostracka in the Third Century", SAOC 51 (Chicago 1992): 249.

${ }^{9}$ Nagy, "Demotic Accounts", 12.

${ }^{10}$ Nagy, "Demotic Accounts", 11- 12.
} 
As for the use of inks, red ink was not used to distinguish some elements as before, but there were other ways of distinguishing by using a number of secondary elements are as follows ${ }^{1}$ :

\begin{tabular}{|l|l|l|l|}
\hline Terminal Marks & Stress Marks & Partition Marks & Checking Marks \\
\hline
\end{tabular}

A-Checking Marks:

In six categories; Oblique Strock, Horizontal Police, Vertical Strock, Curved Strock, Dot, Opposition (cross) ${ }^{2}$.

We have to remember that these signs usually fall in the beginning, but in some cases they are in the end and all those signs Used in accounts and most of them are used slanted police while others do not occur, sometimes used before the specified name or names may be the sum of money or any distinct element in the account.

\section{B- Partition Indications}

The first is the two categories of blank space, which are regular or irregular, vertical or horizontal, and the second lines are also used to separate an account from another account or to separate a section of the account from the other ${ }^{3}$.

\section{C- Strict Marks}

Are signs that exist to give more emphasis on the words or sentences within the texts for that purpose are found on some words or letters form circle or semi-circle and mostly used in the ostraka ${ }^{4}$, Monson ${ }^{5}$ that the drawing of a concentration on those elements ring found to distinguish certain elements from others.

(D) Terminal Marks:

In two categories; double oblique strock, cross mark these marks are usually used to fill gaps or gaps at the end of the account to give the chance of addition, especially on the ostraca ${ }^{6}$.

\footnotetext{
${ }^{1}$ Nagy, "Demotic Accounts", 13.

2 Abdel Halim Nureldin, "Checking Terminal Stress Marks , Partition Indication and Margin lines in Demotic Documents", Enchoria 9 ( 1979 ): 49.

${ }^{3}$ Nureldin, "Checking Stress Marks", 56.

${ }_{5}^{4}$ Nureldin, "Checking Stress Marks", 57-58.

5 Andrew Monson, "Agriculture and Taxation in Early Ptolemaic Egypt", Papyrologische Texte und Abhandungen 46 (2012): 113.

${ }^{6}$ Nureldin, "Checking Stress Marks", 81-82.
} 


\section{Conclusion:}

A- The unit that combines the texts and the lists and is included under the mathematical concept is a general unit in terms of the written appearance, but if we look at the internal classification we find that there are some species in the lists do not fall under the category of arithmetic such as inventories, names and orders of materials and clothing.

B- Differences between the tax records, daybooks, the distribution schedules, the accounting tables, the distribution of wages, dues, food orders and the lists of commodities. The tabular form was taken.

C- The arithmetic texts that were written in the era of the Old and Middle kingdom and the beginning of the modern kingdom took the tabular form. The late modern era and the period of the demotic and Coptic writing found the calculations in the form of accounting-lists form (see Table 2), which is close to the literary form, He wanted to occupy all the space for writing.

D- The diversity of titles carried by book guards in ancient Egypt reflects a more diverse character than the Coptic and Greek fonts.

E- The method of writing the arithmetic text in both the Old and Middle kingdom is more detailed and includes several elements, but in the Demotic and the Coptic it is based on the mention of three basic elements and detail, which is no longer the main concern.

F- We find the use of the marks of the check Checking Marks and we also find Partition Marks Stress Marks and Terminal Marks both and continued until Coptic. 


\section{List of Abbreviation}

ASAE: Annales du Service des Antiquités de l'Égypte (SAE) (Cairo).

BdE: Bibliothèque d'Étude (IFAO, Cairo)

CD: Crum, W., A Coptic Dictionary, Abandon, 1929.

CDD: Johnson, J., The Demotic Dictionary of the Oriental Institute of the University of Chicago, Chicago, 2001.

CENIM: Cahiers Égypte Nilotique et méditerranéenne.

DELC: Dictionnaire étymologique de la langue Copte', by W. Vycichl, 1983.

Er. Glossar: Erichsen, W. Demotisches Glossar. Munksgaard, Kopenhagen 1954.

Faulkner, CD: Faulkner, R., Concise Dictionary, Oxford , 1961.

GNS: Gardiner, A., Notes on the Story of Sinuhe , Librairie Honoré Champion, 1916 .

Hanning, Wb: Hanning, R., Handworterbuch, Die Sprache der Pharaonen. Großes Handwörterbuch Ägyptisch- Deutsch: (2800- 950 v. Chr.) (Kulturgeschichte Der Antiken Welt, Band 64), Berlin, 1995.

Jea: Journal of Egyptian Archaeology (EES, London).

JNES: Journal of Near Eastern Studies (Chicago).

KAW: Kulturgeschichte der Antiken Welt (Mainz am Rhein)

KRI: Kitchen, A., 'Ramesside Inscriptions, Historical and Biographical. I - VII' (Oxford, 1969-1990)

LA: 'Lexikon der Ägyptologie', 7 vols., ed. W. Helck, E. Otto, W. Westendorf, 1972/5-, Wiesbaden .

LD: Lepsius, K., Denkmäler aus Ägypten und Äthiopien', 6 vols., ed. K. R. Lepsius, Berlin ,1849-1859 .

LED: Lesko, H, Late Egyptian Dictionary, 4 Vols, United States America, 1982.

LEM: 'Late- Egyptian Miscellanies', A. H. Gardiner, 1937 (Brussels; BAe 7).

MDIAK: Mitteilungen des Deutschen Archäologischen Instituts, Abteilung Kairo (DAIK) (Mainz/ Cairo/ Berlin/ Wiesbaden).

SAK: Studien zur Altägyptischen Kultur (Hamburg).

Urk: 'Urkunden des ägyptischen Altertums', 8 vols. ed. K. Sethe, H. W. Helck, H. Schäfer, H. Grapow, O. Firchow (Leipzig/ Berlin), 1903-1957.

Wb: Wörterbuch der ägyptische Sprache', 7 vols., A.Erman and W. Grapow, 1926-1931.

ZAS: zeitschrift für ägyptische sprache und altertumskunde, Berlin (1863-1924). 


\section{References}

\section{Arabic References:}

Iman El Mahdi, Bread in Ancient Egypt (Cairo: Egyptian General Book Authority 2009).

Khaled Awad, Grain Stores in Ancient Egypt (Cairo: Ain for Human and Social Studies and Research 2007).

\section{Arabic Thesis References:}

Islam Amer, "Census of Cattles in ancient Egypt until the end of the era of the new kingdom" (unpublished Master thesis, Alexandria University, Faculty of Arts, 2011).

Mohamed Sherif, "A collection of administrative hierarchies in the Egyptian Museum" (comparative linguistic study), (unpublished MA thesis, Faculty of Archeology, Cairo University, 1989).

Mohammed Ali, "Titles and civil functions in the era of the new kingdom" (unpublished MA thesis, Mansoura University, Faculty of Arts, 2012).

Mohammed Saleh, "Economic Life through Ancient Egyptian Literature" (unpublished $\mathrm{PhD}$ thesis, Alexandria University, Faculty of Arts, 2013).

Soad Abdel Aal, "Correspondence through Demotic Documents" (unpublished Master Thesis, Cairo University, Faculty of Archeology, 1983).

Zeinab Mahrous, "Taxation in Ancient Egypt to the End of the new kingdom" (unpublished Master Thesis, Cairo University, Faculty of Archeology,1986).

\section{Foreign References:}

Abdel Kader Muhammed, "The Hittite Provincial Administration of Conquered Territories", ASAE 59, 1966.

Abdel Mohsen Bakir, Egyptian Egistolography, Bibliotheque d'Etude 48, (Cairo: Bibliotheque d' Etude 48, 1979).

Abdel Moneim Abubakr, Excavationa at Giza, I (Cairo: Government Press, 1953).

Abdel Rahman AL-Ayedi, Index of Egyptian Administrative, Religious and Military Titles of the new kingdom (Egypt: Obelisk Publications, 2006).

Adolf Erman, The Ancient Egyptians, A sourcebook of their writings translated by blackman (London: Harper \& Row, 1978).

Ahmed Fakhry, "A Report on the Inspectorate of Upper Egypt" ASAE 46, (1947).

Alan Gardiner, Hieratic Papyri in the British Museum 3rd Series, Chester Beaty Gift, Vol 1 (London: British Museum, 1935). , "The Dakhla Stela", JEA 19, (1933).

- The Royal Canon of Turin ,Griffith Institute (Oxford: Griffith Institute at the University, 1959).

- Admonitions of an Egyptian Sage, from a hieratic papyrus in Leiden Pap. Leiden 344 recto, (Leipzig: Hinrichs, 1909).

Alexandre Scharff, "Pap.Boulaq 18", ZAS 57 (1922).

Andrew Monson, "A Demotic Granary Account from the Early Ptolemaic Fayyum : P.Stanford Classics Dem 8 and 11", CENIM 14, Montpellier (2016). 
--------------, "Agriculture and Taxation in Early Ptolemaic Egypt", Papyrologische Texte und Abhandungen 46 (2012).

Annette Imhausen, Mathematics in Ancient Egypt (Berlin: Princeton University, 2016).

Bertha Porter; Rosalind Moss, Topographical Bibliography of Ancient Egyptian Hieroglyphic Texts, Statues, Reliefs and Paintings, Volume I (Oxford: Griffith Institute, 1960).

Brian Muhs., "Demotic and Greek Ostracka in the Third Century", SAOC, 51 (1992).

Christopher Eyre, The use of Documents in Pharaonic Egypt (Oxford: Oxford Scholarship, 2013).

David Lorton, The Juridical Terminology of international relations in Egyptian texts through dyn.xviii (London: Johns Hopkins University, 1974).

Denise Doxey, Egyptian Non-Royal Epithets in the Middle Kingdom, A Social and Historical Analysis (Leiden : Boston, Brill, 1988).

Dimitri Meeks, Dictionnaires et lexicographie de l'égyptien ancienne, Cairo: Bibliotheca Orientalis 56/5-6 1999)

---------., Annee Lexicographique (Paris: Impr. de la Margeride 1980).

Dois Dunham, Naga ed Der Stelae From First Intermediate Period (Boston: Museum of fine arts 1937).

Donker van Heel; J. Haring, "Writing in A workmen village: Scribal Practice in Ramiesside Deir-Elmadina", Egyptologische utgaven 161 (2003).

Edda Brescioni, "Registrazione catastale E Idologia Politica nell Egitto Tolemaica-A Completame nto Di la Spedizione Di tolomeo, II , insiria in un ostrakon Demotico inedito da Karnak ", EVO 6 (1983).

Eid Nagy, "Demotic Accounts" (MA Thesis, Cairo University, Faculty of Archeology, 2016).

Eric Peet, "The Unit of Value Saty in papyrus Boulaq ii", Melanges Maspero I, (1935).

Fayza Haikal, "A Letter of The Middle Kingdom", ASAE 70 (1984-1985).

Francis Griffith, The Petrie Papyri: hieratic papyri from Kahun and Gurob; principally of the Middle Kingdom, (London: Quaritch 1897). , "The Abydos Decree of Seti 1 at Nauri", JEA 13 (1927).

, Hieratic papyri from Kahun and Gurob principally of the middle kingdom (London: Quaritch 1898).

Garcia Moreno., "La Population Mrt : Une Approche du Probleme de la Servitude, dans L Egypt du iii Millenaire, I", JEA 84, 1998.

Geoffrey Martin, The tomb of Hetepka and Other Reliefs and Inscriptions from the Sacred Animal Necropolis, North Saqqara (London: Egypt Exploration Society 1964-73 1964-73).

Gerges Matta, "Demotic Ostraca From The Collection at Oxford, Paris, Berlin, Vienna, and Cairo" ( Cairo: Impr. de l'Institut français d'archéologie orientale 1945) .

Gorge Fischer., "A Scribe of the Army in a Saqqara Mastaba of the Early Fifth Dynasty" , JNES 18 (1959) .

Gustave Lefebvre, Histoire des grand pretres d'Amon de Karnak (Paris: Cambridge University Press 1929). 
- Inscriptions des grands Pretres d'Amon de Karnak (Paris: Cambridge University 1930).

Heinrich Schafer, Ein Bruchstuck Altagyptischer Annalen (Berlin: akademie der wissenschaften 1902).

Henry Gauthier, "Rapport sur une campagne de fouilles à Drah abou'l Neggah", BIFAO 6 (1908) .

James Henary, The Hekanakht Papers and other Early Middle Kingdom documents (New York: Metropolitan Museum 1962).

Jac Janseen, "Prolegomna to the study of Egypt economic History During the New kingdom", SAK 3 (1974)

-----------, Two Ancient Egyptian Ships Papyrus Leiden I 350 Verso, and Papyrus Turin 2008 (Leiden: Brill 1961).

Jarsolav Cerney, "Community of Workmen in Thebes in Ramesside Period", Bifao 50 (1973).

Jarsolav Cerny; Alan Gardiner, Hieratic Ostraca (Griffith Institute at the University Press, 1957).

De Morgan, Catalogue des Monuments et Inscriptions de l'Egypte antique, Vol , I (Vienna: Holzhausen1894).

Jean Marie Kruchten, Le décret d'Horemheb. Traduction, commentaire épigraphique, philologique et institutionnel (Bruxelles: Université de Bruxelles 1981).

Jon Taylor, Wall Painting and Monuments of EL- Kab IV , The Tomb of Renni , (London: Quaritch 1900).

Mandiville Richard, Wage Accounting in Deir el-Medina, (London: United Kingdom Abercromby Press 2014).

Manily Blackman, The Story of King Kheops and the magicians: transcribed from Papyrus Westcar (Berlin Papyrus 3033), (Australia: J.V. Books 1988).

Margret Murray, Index of Names and Titles of the old kingdom (London: Office of British School of Archaeology 1908).

Mark Jan Naderhof, Papyrus Westcar (Berlin Papyrus 3033) (London: RHB 2009).

Mounir Magally, Notion de comptabilité à propos du papyrus E3226 du Musee du Louvre (Cairo: Institut français d'archéologie orientale 1977).

Norman Davies, Macadam Miles A Corpus of Inscribed Egyptian Funerary Cones I (Oxford: Oxford University Press 1957).

Norman Davies, "Some Representations of Tombs from the Theban Necropolisin", JEA 24, (1938).

Metropolitan Museum of Art 1973).

- "The Rock Tombs of Dier El Gebrawi", 1, Archaeological Survey of Egypt 12 (1900) .

1865-1941)

, The Tomb of Kenamun (New York: Metropolitan Museum of art

---------, "Receuil de Cones Funeraires", Mission archéologique française au Caire 8 (1893).

Paul Smither, "A Tax-Assessor's Journal of the Middle Kingdom", JEA 27, (1941). 
Prier Montet, Les Scenes de la vie privee dans les tombes aux egyptiens de l'Ancien Empire, Chapter, iv, le recen sement des tropeaux (Paris: Revue belge de Philologie et d'Histoire 1925).

Prosener-Krieger ,p., \& de Cenival ,L., Hieratic Papyri in British Museum ,Abu Sir Papyri, 5 th Series, (London 1968).

P. Walcot, "Hesiod and the Instrucion of Onchsheshonqy ", JNES 21, (1962).

Ricardo Caminos, Literary Fragments in the Hieratic Script, LEM, (1956).

Robert Du Mensil, Les Noms et Signes Egyptiens Designant des Vases (Paris: Geuthner 1945).

Robert Grandford, Redford Encyclopedia III (Oxford: Oxford University Press2001).

Robert Ritner, The Instruction of Onchsheshonqy (p. British Museum 10508) in: Simpson, W.K., The Literature of Ancient Egypt (Cairo: Yale University Press 2003).

Rodolf Donald, "Pharaonic King-lists, Annals and Daybooks" a contribution to the study of the Egyptian sense of history" ,SSEA, Book 4 (1986).

Rodulf Anthes, "Die Nominalbildungen irwt Zeremonien und irw Benehmen und Abrechung", MDIAK 24 (1969).

Schafik Allam, Hieratische Ostraka und Papyri aus der Ramessidenzeit, (Tubngen: Postfach 1973).

Selim Hassan, Excavation at Giza, Vol. II (Cairo: Government Press 1936).

Stephen Quirke, Administrative Texts, Redford Encyclopedia, 1 (1998).

Tom Plank; Lois Plank, Encyclopedia of Accountting System, Sedond Eddition, Volume 1 (New York: Prentice Hall, 2005).

Von Bissing Kees, Das Ra-Heilegtum des Konig Ne-Wsr- Ra, vol. II (Leipzig: Hinrichs, 1905-1928).

W.Von Beckerath, "šmsy hִrw in der agyptischen vor-und fruzeit", MDIAK 14, (1956).

Walter Reinike, "Waren die šwtyw wirklich kaufleute", AF 6 (1979).

William Simpson, Papyrus Reisner, ii (1965).

2003). 


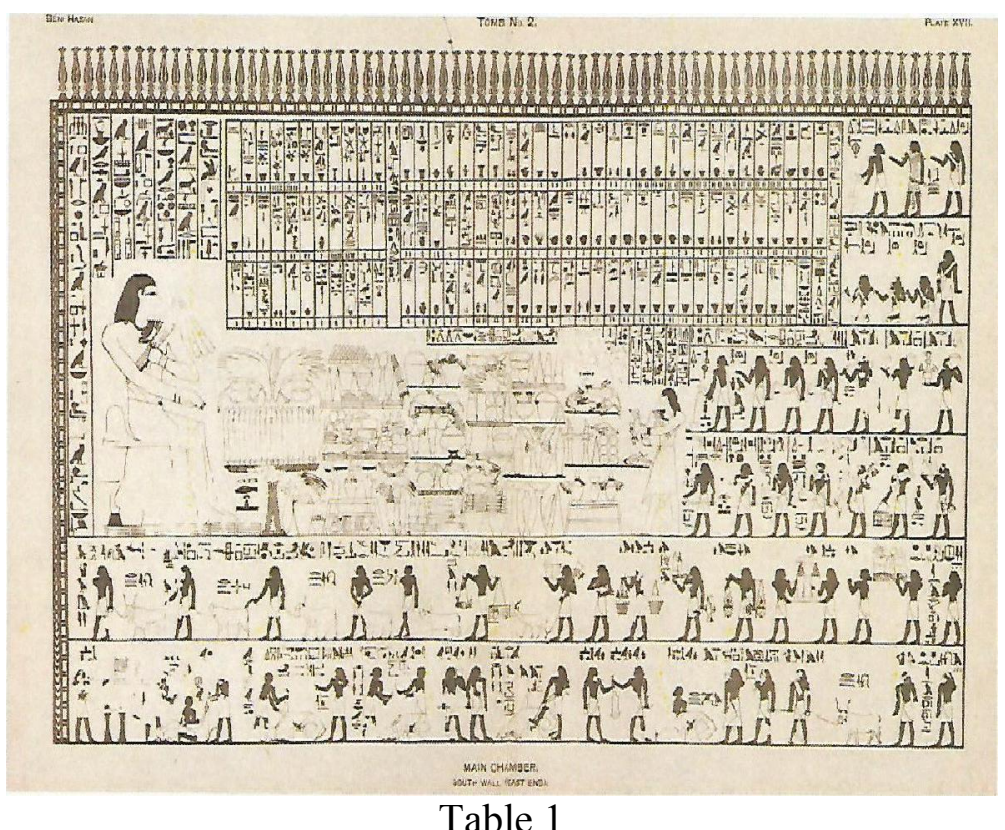

The scene represents the recording of some accounts of the sacrifices that were written in tabular form and illustrated on the southern wall of the main chamber of the Amini cemetery in Bani Hassan

Nagy, "Demotic Accounts", 238

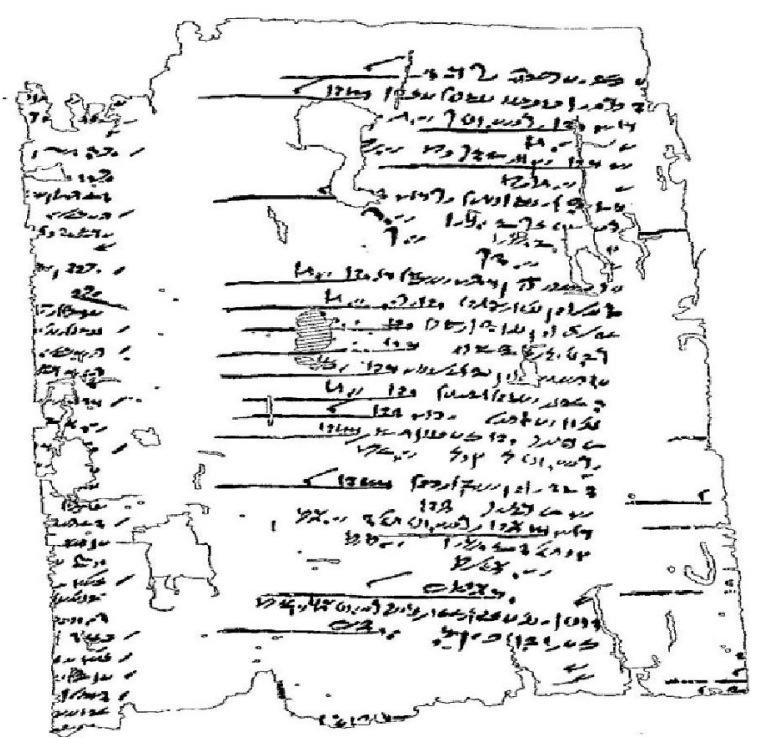

Table 2

The landscape is a facsimile of Brooklyn 37.1647E, D (1) / 2

In which the arithmetic text was written in accounting-lists form

Nagy, "Demotic Accounts", 242. 